\title{
$\mathrm{VX} 2$ 癌移植家鬼顎下腺の組織化学的研究
}

\author{
九州霜科大学大学院蒾学研究科口腔外科学第 2 專攻 (指導 : 梶山 稔教授) \\ 少玉高広
}

炤和 62 年 12 月 23 日受付

\section{A Histochemical Study of the VX2 Carcinoma Transplanted Submandibular Glands of Domestic Rabbits}

Takahiro Kodama

The Second Department of Oral Surgery (Director: Prof. Minoru Kajiyama) Kyushu Dental College, Kitakyushu, Japan

The oral cancer in its early stage is known to invade the surrounding tissue and jaw bones. The structure of the oral cavity is very complex anatomically and the mode of invasion and growth of the oral cancer are also varied. In order to provide proper treatment, therefore, it is necessary to have thorough knowledge of the way in which the oral cancer invades and proliferates in the surrounding tissue. The author therefore transplanted $\mathrm{VX} 2$ carcinoma in the submandibular glands of domestic rabbits and the changes in the submandibular gland tissue with proliferation of the tumor were investigated histopathologically and enzyme-histochemically.

The results were as follows:

I. Histological findings

The VX2 carcinoma tissue transplanted in the submandibular glands proliferated and grew weekly. Along with this, the terminal portion showed such regressive changes as atrophy, deformation and pyknosis of the acinous cells, and the intercalated portion and the striated portion showed atrophy and pyknosis of the epithelial cells of duct. The PAS positive substance in the acinous cells of the terminal portion was also decreased. These regressive changes were increased in the extent weekly.

II . Enzyme-Histochemical findings

1. Succinate dehydrogenase $(\mathrm{SDH})$ reaction

With the proliferation of the tumor tissue, the acinous cells of the terminal portion and the epithelial cells of duct of the intercalated portion and of the striated portion in the surrounding submandibular gland tissue showed gradual decrease in reaction. These findings were found markedly in the area in contact with the tumor tissue and histologically overlapped in the extent with such regressive changes as atrophy and deformation of cytoplasm and pyknosis of the nucleus in the acinous cells of the terminal portion and in the epithelial cells of duct of the intercalated portion and of the striated portion.

2. Lactate dehydrogenase $(\mathrm{LDH})$ reaction 
The acinous cells of the terminal portion in contact with the tumor tissue showed gradual decrease in reaction weekly along with the proliferation of the tumor tissue. Histologically the reactions overlapped in the extent with such regressive changes as atrophy, deformation and pyknosis of the acinous cells of the terminal portion and pyknosis of the nucleus. However, the epithelial cells of duct of the intercalated portion and of the striated portion in contact with the tumor tissue showed gradual decrease in reaction beginning with the cases of three-week after transplantation and about in concurrence with such regressive changes as atrophy of cytoplasm and pyknosis of the nucleus.

3. Acid phosphatase (ACP) reaction

The reaction of the acinous cells of the terminal portion in contact with the tumor tissue gradually increased beginning with the cases of two-week after transplantation and histologically overlapped with the area where atrophy and deformation of the acinous cells of the terminal portion and pkynosis of the nucleus were marked. However, the epithelial cells of the intercalated portion and of the striated portion showed gradual decrease in reaction beginning with the cases of three-week after transplantation about in concurrence with atrophy of cytoplasm and pyknosis.

\section{Alkaline phosphatase (ALP) reaction}

With the proliferation of the tumor tissue, the myoepithelial cells of the terminal portion in contact with the tumor tissue showed gradual decrease in reaction. Histologically, the reactions about overlapped in area with such regressive changes as atrophy, deformation and pyknosis of the acinous cells of the terminal portion.

5. Non-specific esterase (EST) reaction

With the proliferation of the tumor tissue, the acinous cells of the terminal portion and the epithelial cells of duct of the intercalated portion and of the striated portion showed gradual decrease in reaction weekly. Histologically, the reactions about overlapped in area with such regressive changes as atrophy and deformation of the acinous cells of the terminal portion and atrophy and deformation of cytoplasm of the intercalated portion and of the striated portion and pyknosis of the nucleus.

6. The foregoing changes in enzymic reaction were intensified especially at the area surrounded by the tumor tissue and at the submandibular gland tissue of the area directly in contact with the tumor tissue. Further away from the tumor tissue, the less were the changes. Histologically, these changes overlapped in area with such regressive changes as atrophy, deformation and pyknosis of the acinous cells of the terminal portion, atrophy and deformation of cytoplasm of the intercalated portion and of the striated portion and pyknosis of the nucleus.

7. The foregoing experimental results showed that the invasion and proliferation of VX2 carcinoma tissue induced morphological regressive changes in the submandibular gland tissue and also affected such functional aspects as synthesis and excretion of the secretory substance. Furthermore, the invasion and proliferation induced changes in enzymic reaction of the acinous cells and myoepithelial cells of the terminal portion and 
in that of the epithelial cells of duct, and also affected the metabolic mechanism of the submandibular gland tissue.

Key words : VX2 carcinoma/Submandibular gland/Histochemistry/Domestic rabbit

緒 言

口腔癌が比較的早期に周囲軟組織や顎骨を浸潤するこ とはすでに知られている1-8)。とくに顎・ロ腔領域では その構成が解剖学的にもきわめて複雑で, 浸潤発育様式 も多種多椂である ${ }^{3-111}$ ， 口腔癌に 対する治療法は他科 領域に扔ける癌治療 ${ }^{12}$ 之同様に, 外科的療法, 放射線 療法, 化学療法などによる集学的な治療法が実施されて いる13-20)。しかしながら，口腔という特殊性から，治 療後における形態や機能の保持という重要な問題が残さ れ，治療後の障害をできうるだけ回避する適切なる治療 法が望まれる。したがって，より適確な治療を実施する にあたっては, 口腔癌の周囲組織への浸潤増殖態度を熟 知しておくてとが肝要である。

このような観点から，てれまでに口腔癌モデルとし て, 発癌物質や移植腫煌を用いた研究が多数報告されて いる21-40)。当教室においても臨床的には梶山ら（19

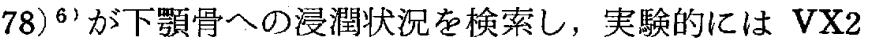
癌を用いて, 安藤 $(1971)^{283}$ が 上䫇洞で, 外山 (1978) $\left.{ }^{36}\right)$ は舌で, 中尾 $(1986)^{40}$ は歯肉と, それぞれ周囲組 織や隣接臟器で浸潤, 增殖態度を検索し, 報告してい る.

一方, 囯液腺を対象として, 発癌過程やその増殖状況 を病理組織学的に研究した報告は多くみられる22-24， 29,31,33-35,37)。しかしながら，移植腫場を顎下腺に 移植し，増殖態度について検索した報告は少なく，島田 $(1960)^{22}$ ， 川勝ら $(1969)^{27}{ }^{27}$ 执よび当教室の中村 $(19$ 84) ${ }^{39}$ ） らの報告があるにすぎず，堌殖態度を醳素組織化 学的に検索した報告はほとんどみられない．

著者は家鬼の罰下腺に VX2 癌を移植し, 腫崵の増殖 にともなう顎下腺組織の態度を病理組織学的ならびに醉 素組織化学的に検索し，知見を得たのでその成績を報告 する。

\section{実験材料ならびに実験方法}

I . 実験材料

A . 実験動物

体重約 $2.0 \mathrm{~kg}$ 前後の成熟雑系雄性家鬼，60頭を実験に 使用した. 家鬼は購入後, $1 \sim 2$ 週間, 固型飼料 (ORC
4，オリエンタル醅母社製）および水道水を同一条件下 で飼育し, 恒温条件下の飼育室にて予備飼育し, 十分環 境に順応させたのち, 実験に供した。

\section{B . 実験腫湯}

移植腫瘍は家鬼に可移植性で，ヒトの口腔癌のうち， 最も多い扁平上皮癌に類似した組織型を有する $\mathrm{VX} 2$ 癌 30,39・42) 使用した。なお，VX2 癌は愛知ガンセンタ 一・ウィルス部より当教室にて家兔の大腿筋肉内で, 累 代移植，維持されているものである.

II . 実験方法

A. 移植方法

家象の大腿筋肉内に累代移植されている VX2 癌組織 を無菌的に切除し, 正常筋肉や壊死部を可及的に除去し た.ついで, 腫煌組織片を phosphate bufferd saline にて十分洗浄したのち, 細切し, \#50〜100ゲージの白 金メッシュで濾過，その細胞浮遊液を 800〜1000 rpm,

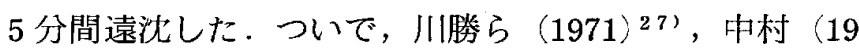
84 ${ }^{391}$, 中尾 $(1986)^{40}$ ' らの方法に準じて, 腫煌細胞数 が $5 \times 10^{5}$ 個 $/ \mathrm{ml}$ となるように，5\%の仔牛血清を含ん だ Eagle の minimum essential medium にて調整 し，移植腫瘍とした。

顎下腺への移植は顎下部に約 $3 \mathrm{~cm}$ の皮切を加え, 周 囲組織を鈍的に剝離し，顎下腺を露出したのち，ッベル クリン用注射針にて顎下腺の被膜下へ，腫瘍細胞浮遊液 $0.5 \mathrm{ml}\left(2.5 \times 10^{5}\right.$ 個 $)$ を注入, 移植した。

\section{B . 観察方法}

予備実験の成績から移植後 $4 \sim 5$ 週で顎下腺の湿重量 が, 正常堮下腺の $3 \sim 4$ 倍となり, しかも顎下腺を充満 した腫瘍組織が周囲組織へと漫潤，増殖したため，観察 期間を 1〜 4 週までとした。

移植した家兔は所定期間飼育後，顎下腺機能を一定に するために，15〜18時間絶食させたのち，屠殺し，纐下 腺を摘出した。摘出顎下腺は直ちに中央部で矢状断に割 断し，すみやが O.C.T. Compound (Lab-Tek Products）により $-20^{\circ} \mathrm{C}$ で包埋し， $-20^{\circ} \mathrm{C}$ のクリオスタ ット内で, $5 \sim 8 \mu \mathrm{m}$ の新鮮凍結切片を作成し, コハク 酸脱水素䤃素・ succinate dehydrogenase（以下 SDH と略す), 乳酸脱水素酵素・ lactate dehydrogenase (以 下 LDH と略す), 酸性フォスファターゼ・acid pho- 
sphatase (以下 ACP と略す), アルカリフォスファター ゼ・alkaline phosphatase (以下 ALP と略す)，非特 異的エステラーゼ・non-specific esterase (以下 EST 之略す)などを酵素組織化学的に検索した。また，摘出 顎下腺の一部は $10 \%$ 中性ホルマリン水溶液に固定し，へ マトキシリン・エオジン重染色(以下 $\mathrm{H} ・ \mathrm{E}$ 染色と略す) および過ヨウ素酸シッフ染色（以下PAS 染色と略す） を施し，鏡検した。

\section{1. $\mathrm{SDH}$ 反店}

佐野（1965） ${ }^{43}$ 'の Tetrazolium 法を応用して，切片 を下記の基質液中で $37^{\circ} \mathrm{C} ， 40$ 分間浸漬し，蒸留水で水 洗，グリセリン・ゼラチンで封入.

基質液 :

$0.1 \mathrm{M}$ Sodium succinate $30 \mathrm{ml}$

$0.1 \mathrm{M}$ Sörensen phosphate buffer $(\mathrm{pH} 7.6)$

.............24ml

$250 \mathrm{mg} \%$ Nitro Blue Tetrazolium chloride

$$
\text { ............ } 6 \mathrm{ml}
$$

$100 \mathrm{mg} \%$ Phenazine Methosulfate $2 \mathrm{ml}$

2. $\mathrm{LDH}$ 反応

佐野 (1965) ${ }^{4}$ ') の Tetrazolium 法を応用して, 切片 を下記の基質液中で $37^{\circ} \mathrm{C}, 20$ 分間浸漬し, 蒸留水で水 洗，グリセリン・ゼラチンで封入.

基質液 :

$0.5 \mathrm{M}$ D,L-sodium lactate $\cdots \cdots \ldots \ldots \ldots \ldots \ldots, 6 \mathrm{ml}$

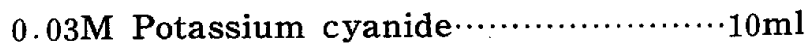

$500 \mathrm{mg} \%$ Nicotinamide Adenine Dinucleotide $6 \mathrm{ml}$

0.1M Sörensen phosphate buffer $(\mathrm{pH} 7.6)$ $20 \mathrm{ml}$

$250 \mathrm{mg} \%$ Nitro Blue Tetrazolium chloride

$$
\text { ........... } 6 \mathrm{ml}
$$

Aq. dest $12 \mathrm{ml}$

3. ACP 反灾

Barka-Anderson（1962４4'の Azo 色素法を灾用し て，切片を下記の基質液中で $37^{\circ} \mathrm{C} ， 60$ 分間浸漬後，烝 留水で水洗, グリセリン・ゼラチンで封入.

基質液：

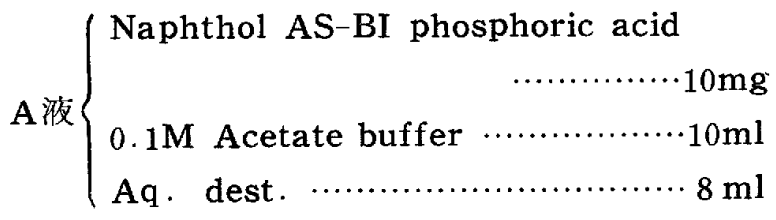

B液 Hexazonium pararosanilin …..... $1 \mathrm{ml}$ A液とB液を混和し， $1 \mathrm{~N}$ の $\mathrm{NaOH}$ で $\mathrm{pH} 5.0$ に修
正後, 蒸留水で $20 \mathrm{ml}$ とする.

4. ALP 反応

Burstone の Watanabe $(1964)^{45}$ ) 変法による Azo 色素法を応用して, 切片を下記の基質液中で $20^{\circ} \mathrm{C}, 10$ 分 間浸漬後, 蒸留水で水洗，グリセリン・ゼラチンで封 入.

\section{基質液：}

Naphthol AS-BI phosphoric acid $10 \mathrm{mg}$ 0.05M 2-Amino-2-methy-1, 3-propanediol

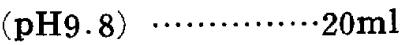

Fast Blue RR Salt $10 \mathrm{mg}$

5. EST 反応

Burstone $(1962)^{46)}$ の Azo 色素法を応用して, 切片 を下記の基質液中で $37^{\circ} \mathrm{C}, 60$ 分間浸漬後, 蒸留水で水 洗，グリセリン・ゼラチンで封入.

基質液：
A液 $\left\{\begin{array}{l}\text { Naphthol AS-D acetate } \cdots \cdots \cdots \cdots \cdot 3 \mathrm{mg} \\ \mathrm{N}, \mathrm{N} \text {-Dimethylformamide } \cdots \cdots \cdots \cdot 5 \mathrm{ml}\end{array}\right.$
B液 $0.1 \mathrm{M}$ Tris buffer (pH7.1) …... 50ml A液とB液を混和し，Fast Blue BB Salt 40mg を 加える.

\section{実 験 成 績}

\section{I 、移植 VX2 癌の組織学的所見}

移植した VX2 癌組織は充実性で，上皮性の腫陽細胞 からなる胞巣と，少量の結合織性の間質からなってい る．腫瘍細胞の形は大小不同の多角形で，核は類円形で 比較的大きく，ヘマトキシリンに淡染し，核優位である (写真 1 )

II . 対照例 (正常家鬼顎下腺)

A. 組織学的所見

正常家兔の顎下腺組織は薄い被膜に包まれ, 少量の結

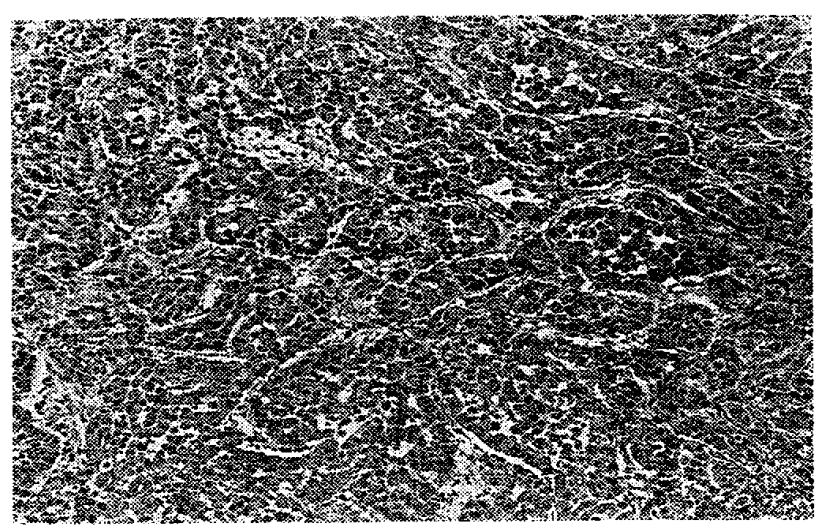

写真 1 移植した VX2癌組織 $(\mathrm{H} \cdot \mathrm{E}$ 染色, 弱拡大 $)$ 
合組織により，明瞭な小葉構造を呈し，終末部の腺房細 胞や介在部および線条部などの導管上皮細胞から構成さ れている。

終末部の腺房紐胞は 2 種類の細胞からなっている。す なわち，1つは細胞の外形が立方形または円錐形で，細 胞質がヘマトキシリンに淡染し，網眼様構造を呈する細 胞で，PAS 染色では弱陽性である．核はクロマチンに 富み，円形ないし楕円形で，基底側に偏在している。他 の1つは, 細胞の外形は前者にほぼ類似しているが, 細 胞質はエオシンに濃染し，PAS 染色では強陽性の物質 が充満している。また，核は前者とほぼ同様な所見であ る. 以上のように終末部の腺房細胞は 2 種類の細胞から なっていたが, 前者が大部分を占めている。

介在部はエオジン好染の立方上皮細胞よりなり，核は 円形ないし楕円形で，クロマチンに富み，わずかに基底 側に位置している。

線条部はエオジン好染の円柱上皮よりなり，核は円形 ないし類円形で，へマトキシリンに焁染し，ほぼ中央に 位置しており，核の下方にはよく発達した基底線条が認 められる．また，導管腔は円形ないし楕円形で，周囲で は毛細血管が散見される(写真 2 )。

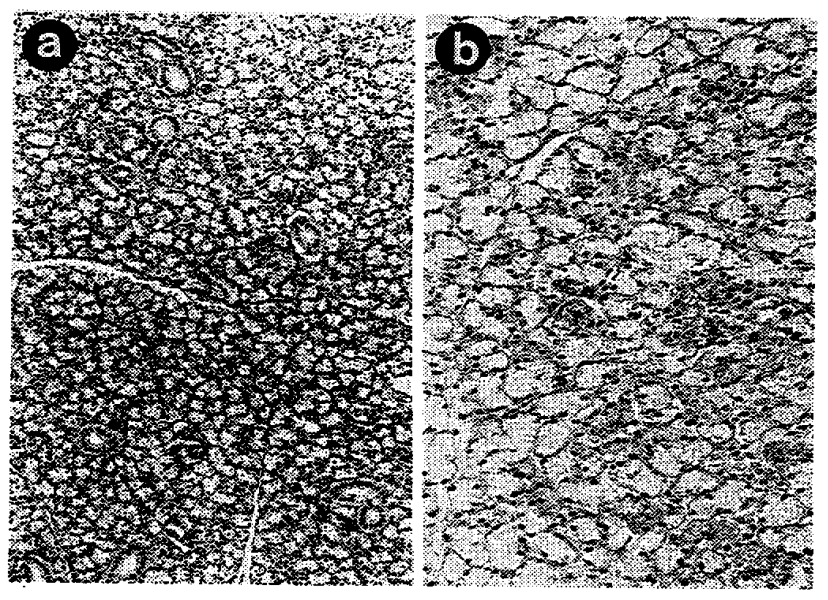

写真 2 正常家躳顎下腺組織（対照例）

$\mathrm{a}: \mathrm{H} \cdot \mathrm{E}$ 染色, 弱拡大, $\mathrm{b}:$ PAS 染色, 強拡大

\section{B. 酵素組織化学的所見}

$\mathrm{SDH}$ 反応：終末部の腺房細胞では, 中等度陽性であ ろが, 介在部や線条部の導管上皮細胞では強陽性であ る.なお，終末部の筋上皮細胞には SDH 反応が認めら れない(写真 $3, a$ ).

LDH 反応: 終末部の腺房細胞では, 强陽性の反忍が みられ, 介在部や線条部の導管上皮細胞でも強陽性に反 応しているが, 終末部腺房細胞に比べ LDH 反応は強度

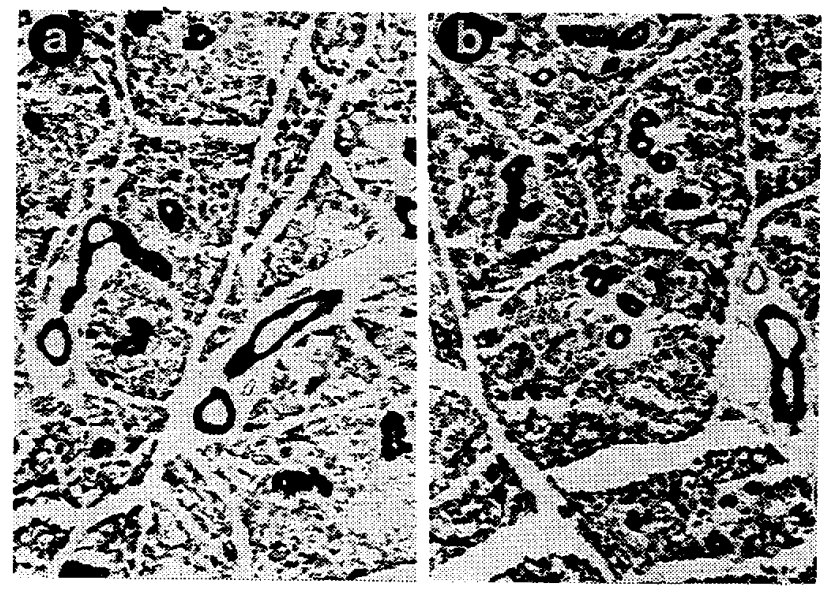

写真 3 正常家鬼䫁下腺組織（刘照例）

a : SDH 反応 (強拡大), 終末部腺房細胞は中等度 陽性，導管上皮細胞は強陽性に反応している。

b : LDH 反応 (強拡大), 終末部腺房細胞, 導管上 皮細胞ともに強陽性に反応している

となっている，なお，終末部の筋上皮細胞には LDH 反 応が認められない（写真 $3, b$ ).

$\mathrm{ACP}$ 反応：終末部の腺房細胞では, 中度等陽性の反 応がみられるが，介在部や線条部の導管上皮細胞では $\mathrm{ACP}$ 反応は弱陽性である。なお，終末部の筋上皮細胞 では ACP 反応は認められない（写真 $4 ， \mathrm{a}$ ).

ALP 反忍：終末部の腺房細胞, 介在部抢よび線条部 の導管上皮細胞では，ともに ALP 反応は認められな い.しかしながら， 終末部の筋上皮細胞では強陽性の ALP 反応が認められる (写真 $4, b)$.

EST 反応：終末部の腺房細胞では，中等度陽性の反 忍であるが, 介在部や線条部の導管上皮細胞では, 強陽 性に反応している。なお, 終末部の筋上皮細胞には EST 反応は全く認められない（写真 $4, \mathrm{c}$ ).

\section{III. 移植後 1 週例}

A. 組織学的所見

$\mathrm{VX} 2$ 癌組織は顎下腺被膜の内側に限局し, 小胞巣を 形成しているが，腺体内への浸潤，增殖は認められな い.なお, 腫場組織に接する腺体では, リンパ球, 好中 球, 形質細胞などの炎症性細胞の浸潤が中等度に認めら れる、また, 同部の終末部腺房細胞では, わずかに萎縮 したものや，核に濃縮のみられるものが散見される．同 部の終末部腺房細胞では PAS 陽性物質が対照例に比 べ, わずかに減少しているものが散見される.一方, 腫 瘍組織に近接する部の介在部や線条部の導管では, 導管 腔に軽度の拡張がみられるが，導管上皮細胞の細胞質や 核に変化はみられず，対照例と同様な所見である。 


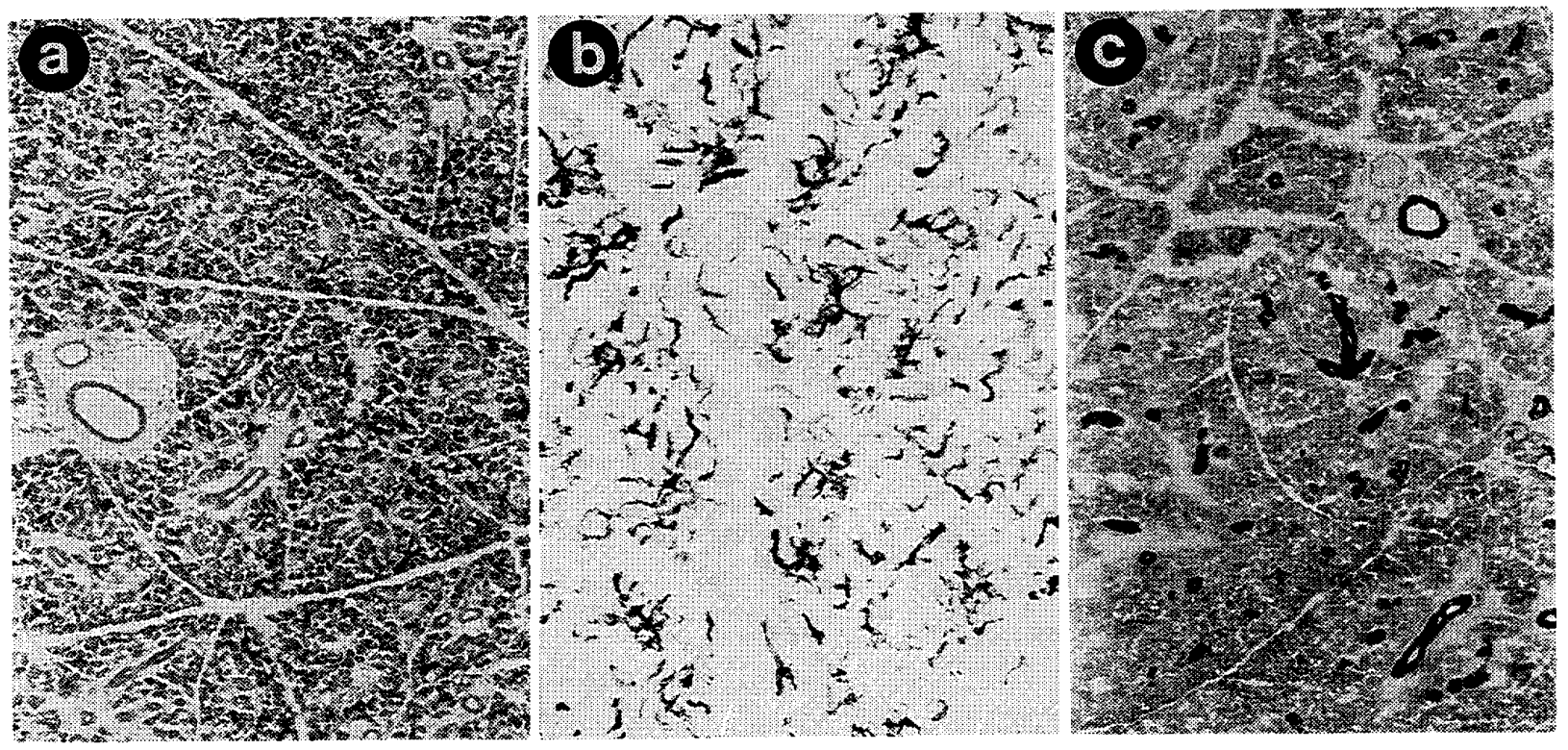

写真 4 正常家鬼顎下腺組織（対照例）

a : ACP 反応 (弱拡大), 終末部腺房細胞は中等度陽性, 導管上皮細胞は弱陽性に反忍している.

b : ALP 反応 (強抾大), 終末部の筋上皮細胞は強陽性に反応している.

c：EST 反応 (弱拡大), 終末部腺房細胞は中等度陽性, 導管上皮細胞は強陽性に反応している.
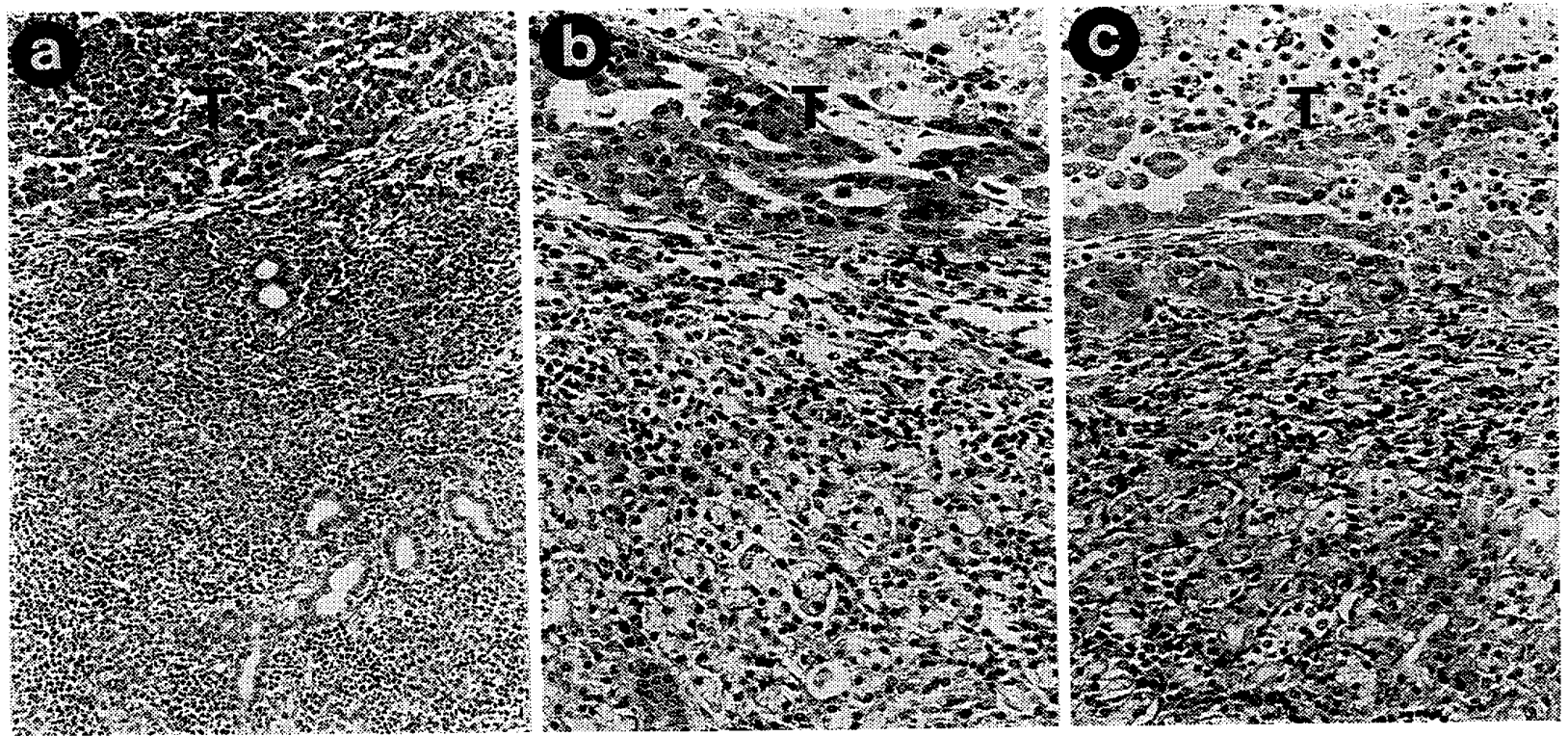

写真 5 移植後 1 週例

$\mathrm{a}: \mathrm{H} \cdot \mathrm{E}$ 染色, 弱拡大, $\mathrm{b}: \mathrm{H} \cdot \mathrm{E}$ 染色, 強拡大, $\mathrm{c}: \mathrm{PAS}$ 染色, 強拡大

腫瘍組織（T）に類下腺被膜下に限局し, 周囲の終末部腺房細胞では, 萎縮, 核の濃縮, PAS 陽 性物質の減少した部が散見される。

以上の所見は $\mathrm{VX} 2$ 癌組織に近接した腺体部に誌めら れ, 他の部では対照例と同様に変化が認められない（写 真 5 ).

B. 酵素組織化学的所見
$\mathrm{SDH}$ 反応：顎下腺の被膜下にみられる VX2 癌組織で は，SDH 反応は痕跡程度である。また，腫瘍組織に接 する終末部の腺而細胞および介在部や線条部の導管上皮 細胞でも対照例の SDH 反応と同程度で，変化は認めら 

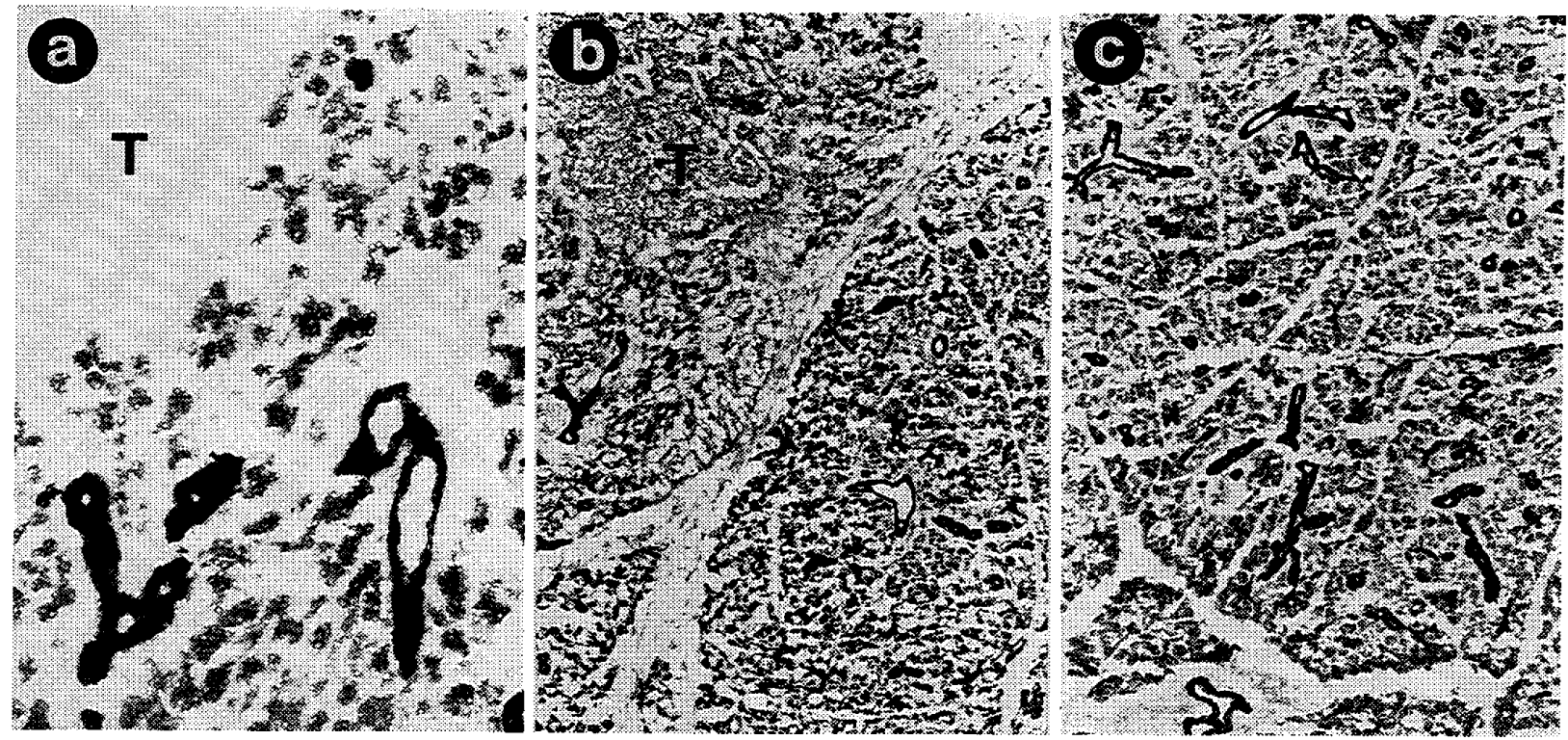

写真 6 移植後 1 週例
$\mathrm{a} ＼textrm{S D H}$ 反応（強拡大），腫碭組織（T）と接する部では変化はみられない，
b : LDH 反応 (弱执大), 腫瘍組織（ $\mathrm{T}$ ）と接する終末部腺房細胞は中等度陽性で, 軽度に低下し ている
c : LDH 反応（弱拡大），腫瘍組織から離れた部では，変化はみられない。

れない。なお，腫湯組織から離れた部でも対照例と同様 で，とくに変化は認められない(写真 $6, \mathbf{a}$ ).

$\mathrm{LDH}$ 反応: 䫈下腺被膜下の VX2癌組織は中等度陽性 である．また，腫煌組織に接する部の終末部腺房細胞で は，対照例に比へ，中等度の陽性と反応がわずかに低下 している，ての LDH 反応が低下している部は組織学的 に終末部腺房細胞が萎縮している部とほぼ一致してい る. 一方, 腫煌組織に接する介在部や線条部の導管上皮 細胞では, ともに $\mathrm{LDH}$ 反応は強陽性で, 対照例との差 異は認められない。なお，腫瘍組織から離れた部のLDH 反応は対照例と同程度である (写真 $6, \mathrm{~b}, \mathrm{c}$ ).

$\mathrm{ACP}$ 反応：顎下腺被膜下にみられるVX2癌組織には 痕跡程度の反応がみられるが, 腫瘍組織に接する終末部 腺房細胞では, 対照例の ACP 反応と同様に中等度陽 性の反応である，看焬組織に直接接している部では, 強 陽性の反応を示す部も散見される。しかしながら, 介在 部や線条部の導管上皮細胞では，ACP 反応は弱陽性で， 対照例のそれと差異は認められない，なお，他の腺体部 での ACP 反心は対照例と同様に終末部の腺房細胞で は, 中等度陽性の反応, 介在部や線条部の導管上皮細胞 では弱陽性反応で，差異はみられない（写真 7，a）。

ALP 反応：顎下腺被膜下における VX2 㫊組織の ALP 反応はみられず, 全く陰性である。また, 腫陽組織
に接する終末部の腺房細胞および介在部や線条部の導管 上皮細胞では, 対照例と同様に ALP 反応は全く認めら れない。しかしながら, 腫煬組織に接した部の終末部の 筋上皮細胞では, ALP 反応は中等度陽性で, 対照例と 比べ反応は低下している，ての終末部の筋上皮細胞にお ける ALP 反応の低下は終末部腺房細胞の萎縮の範囲と ほほ一致してみられる。なお，他の腺体内におけるALP 反応は対照例之同様な所見を呈している (写真 $7, b)$.

EST 反念：顎下腺被膜下の VX2癌組織は弱陽性の反 応で, 腫瘍組織に接する部の終末部腺房細胞では, 組織 学的に萎縮がみられる範囲とほほ一致して, EST 反応 は弱陽性を示し, 対照例に比べ低下している.しかしな がら, 腫焬組織に接する部の介在部や線条部の導管上皮 細胞では，刘照例と同様に強陽性の EST 反応を至して いる.なお，他の腺体部における EST 反応は対照例と 同様に, 終末部の腺房細胞は中等度の陽性, 介在部や線 条部の導管上皮細胞は強陽性にそれぞれ反応し, 対照例 と美異は認められない(写真 $7, \mathrm{c}$ )。

\section{IV. 移植後 2 週例}

A. 組織学的所見

$\mathrm{VX} 2$ 癌組織は顎下腺の被膜下より, 腺体内へ索状ない しは小胞䉾状に浸潤し, 腺体の約 $1 / 4$ まで增殖している. 腫泀組織の先端部では, 終末部の腺房細胞や介在部, 

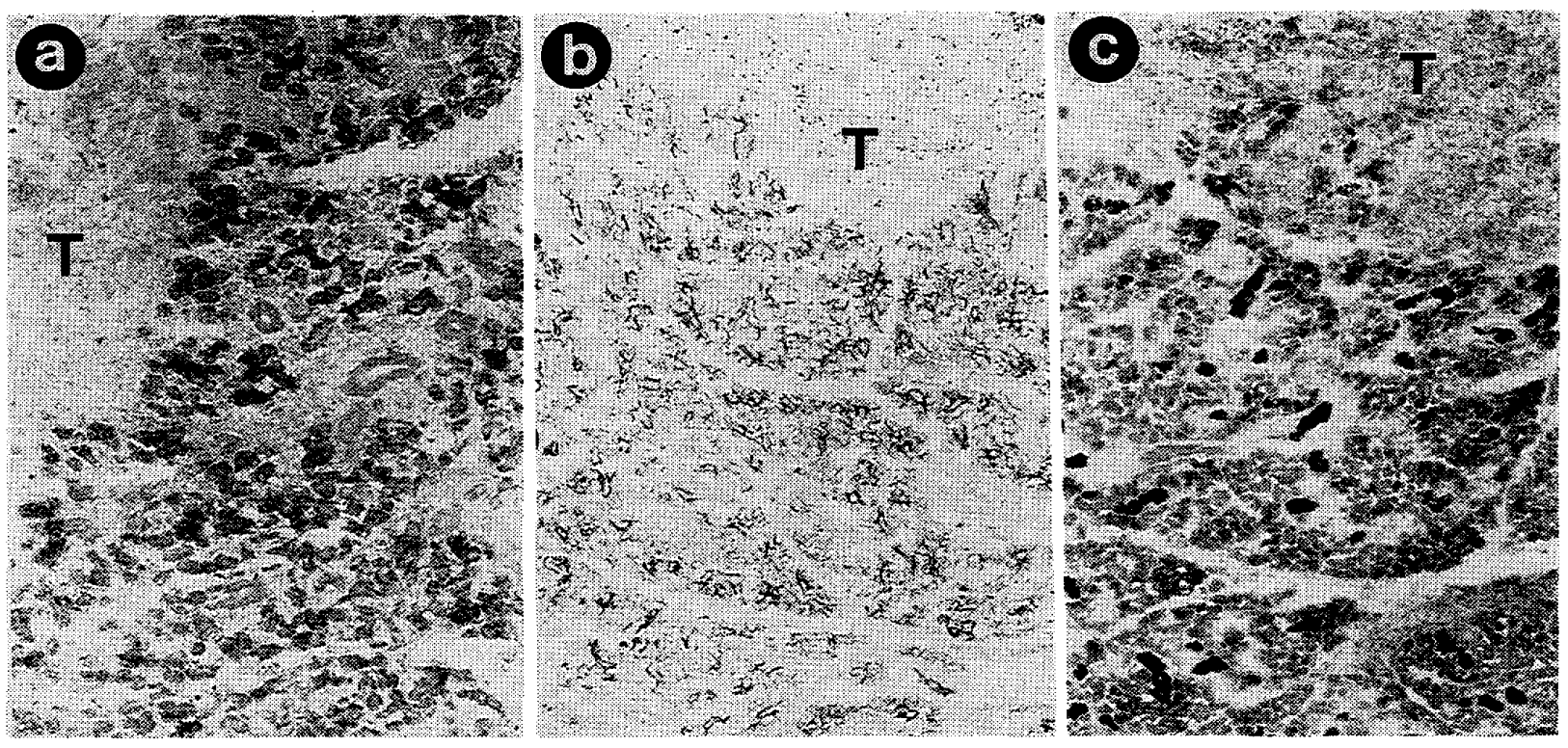

写真 7 移植後 1 週例

$\mathrm{a}$ ：ACP 反応(強拡大), 腫湯組織（T）と接する終末部腺房細胞は一部, 強陽性に反応している.

$\mathrm{b}$ : ALP 反応 (弱拡大), 腫焬組織（ $\mathrm{T}$ ） と接する終末部の筋上皮細胞では, 中等度陽性に反応し ている。

c：EST 反応（弱拡大），腫熛組織（ $\mathrm{T}$ ）と接する終末部腺房細胞は一部，弱陽性に反応している.

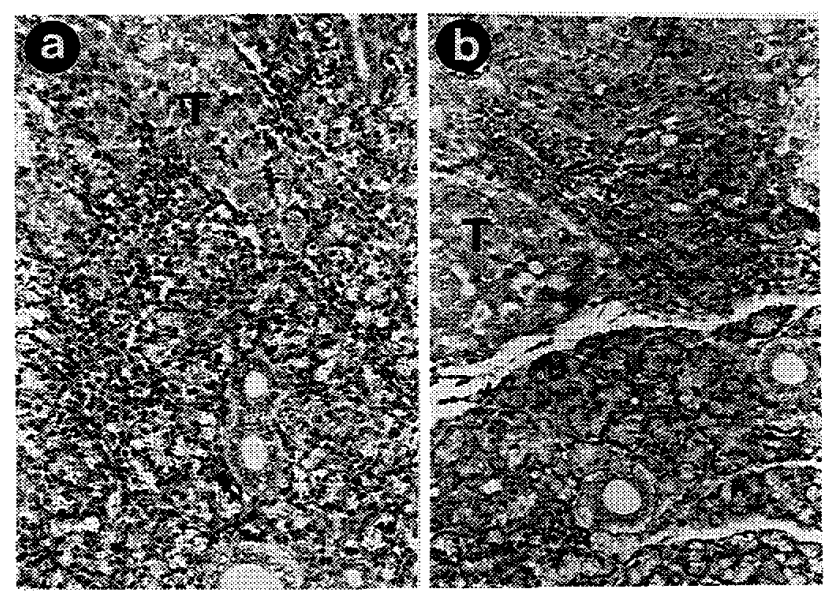

写真 8 移植後 2 週例

$\mathrm{a}: \mathrm{H} \cdot \mathrm{E}$ 染色, 強拡大, $\mathrm{b}:$ PAS 染色, 強拡大 腫湯組織（T）は浸潤性に増殖し，周囲の終末部腺 房細胞は萎縮, 変形, 核の濃縮, PAS 陽性物質の 減少がみられる。

線条部の導管は腫瘍組織に囲繞されている，また，終末 部の腺房細胞では軽度の萎縮と核の濃縮しているものが 認められる。

腫瑒組織に接する腺体部では，炎症性細胞の浸潤が軽 度に認められ, 終末部の腺房細胞は軽度に菱縮し, 核は 濃縮している．また，乙れにともないPAS 陽性物質も
減少している.介在部や線条部の導管上皮細胞では, 細 胞質，核ともに対照例と同様で変化はみられない，ま た, 導管腔は移植後 1 週例々同様に軽度に拡張し, 導管 周囲の毛細血管では，拡張や軽度の无血がいくぶん多く 認められる。

これらの所見は移植後 1 週例に比べ，その範囲がさら に広くなっている(写真 8 )。

B. 䤃素組織化学的所見

$\mathrm{SDH}$ 反応: 腺体内に増殖した $\mathrm{VX} 2$ 癌組織の先端部で は，痕跡程度の反応である。また，腫瘍組織に囲繞され た終末部の腺房細胞は弱陽性に反応し, 対照例と比へ低 下している，さらに，同部での介在部や線条部の導管上 皮細胞でも同様に, SDH 反灾は中等度陽性で, 刘照例 に比べ低下している。

腫煬組織に 接する部の終末部腺房細胞では，SDH 反 応は弱陽性で, 対照例および移植後 1 週例に比べ著しく 低下している：また，介在部や線条部の導管上皮細胞は 中等度の陽性反応で, 対照例や移植後 1 週例に比べ低下 している，以上のように，SDH 反応の低下範团は移植 後 1 週例に比べ，その範囲は広くなり，組織学的には， 終末部腺房細胞の萎縮や核の濃縮などの退行性変化がみ られる部とほぼ一致している。

一方, 腫場組織から離れるにしたがい，終末部腺房細 
胞の SDH 反応は弱陽性から弱陽性ないし中等度陽性へ と移行しいるが，対照例および移植後 1 週例に比べれば やや低下している。しかしながら，腫場組織から離れた 部の介在部や線条部の導管上皮細胞では，SDH 反応は 强陽性となり，対照例や移植後 1 週例とほとんど差異は 認められない(写真 $9, a, b)$.

LDH 反応：中等度に LDH 反応を示す腫煌組織に囲 繞された終末部の腺房細胞は，弱陽性となり対照例に比 べかなり低下している、しかしながら，介在部や線条部 の導管上皮細胞は強陽性で変化はみられない，

腫瘍組織に接する部の終末部腺房細胞では，対照例お よび移植後 1 週例に比べ，LDH 反応は弱陽性で低下し ている。てのような LDH 反応の低下している部は移植 後 1 週例に比べ，さらにその範囲を増しているが，組織 学的に, 終末部腺房細胞の萎縮や核の濃縮などの退行性 変化がみられる部とほぼ一致した範囲である，また，腫 瘍組織から離れるにしたがい，終末部腺房細胞は弱陽性 から中等度陽性と変化している，なお，介在部や線条部 の導管上皮細胞では，腫煬組織に接する部や，腫煬組織 から離れた部でも，ともに強陽性の反応を示し，対照例 および移植後 1 週例と同様にその差は認められない（写 真 $9, \mathrm{c}$ ).
$\mathrm{ACP}$ 反応：増殖した腫場組織の先端部では，痕跡程 度の反応を示している。また，腫湯組織に囲繞された終 末部の腺房細胞は强陽性で，対照例に比べ ACP 反応は 強くなっている。しかしながら，介在部や線条部の導管 上皮細胞は弱陽性で，対照例と同程度である。

腫場組織に接する部の終末部腺房細胞では，強陽性の 反応で，対照例や移植後 1 週例に比べその反応は強度と なっている。しかしながら，腄煌組織から離れるにした がって，ACP 反応は次第に低下し，対照例や移植後 1 週例と同程度の反応である。なお，介在部や線条部の導 管上皮細胞では，ACP 反応が弱陽性で，対照例および 移植後 1 週例に比べ差異はみられない（写真 $10 ， a$ )。

ALP 反応：䫕下腺体内に增殖した腫煬組織には全く 反応が認められない，また，腺体全般にわたって，終末 部腺房細胞および介在部や線条部の導管上皮細胞では， 対照例や移植後 1 週例と同様に，ALP 反态は全く認め られない，一方，腫晹組織に囲繞された終末部の筋上皮 細胞では，ALP 反忘は弱陽性となり，対照例や移植後 1 週例に比べ著しく低下している。 また，腫痬組織に接 する終末部の筋上皮細胞では, 対照例や移植後 1 週例に 比べ弱陽性と著しく低下し，その範囲も移植後 1 週例よ り広範囲となっている，さらに，腫崵組織に接する腺体
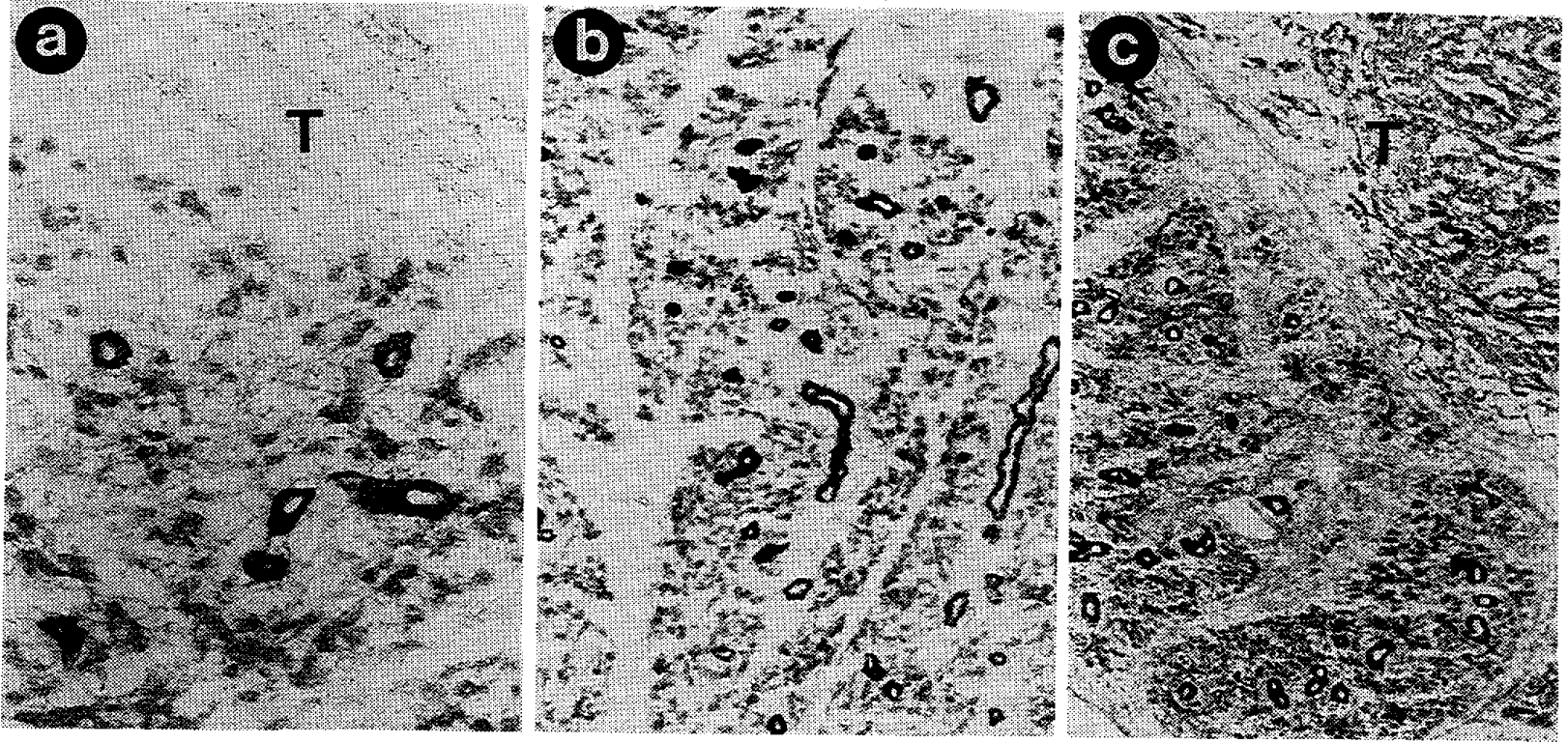

写真 9 移植後 2 週例

$\mathbf{a} ： \mathrm{SDH}$ 反応（強执大），終末部腺房細胞は腫瘍組織（ $\mathrm{T}$ ）と接する部で，弱陽性に低下している．

$\mathrm{b}$ ：SDH 反忍 (弱拡大), 腫煌組織から離れた部で，終末部腺房細胞は弱陽性に低下しているが， 導管上皮細胞では，変化はみられない，

c： $\mathrm{LDH}$ 反応（弱拡大），腫瘍組織（ $\mathrm{T}$ ）と接する終末部腺房細胞は弱陽性に低下しているが，導 管上皮紐胞では，変化はみられない。 

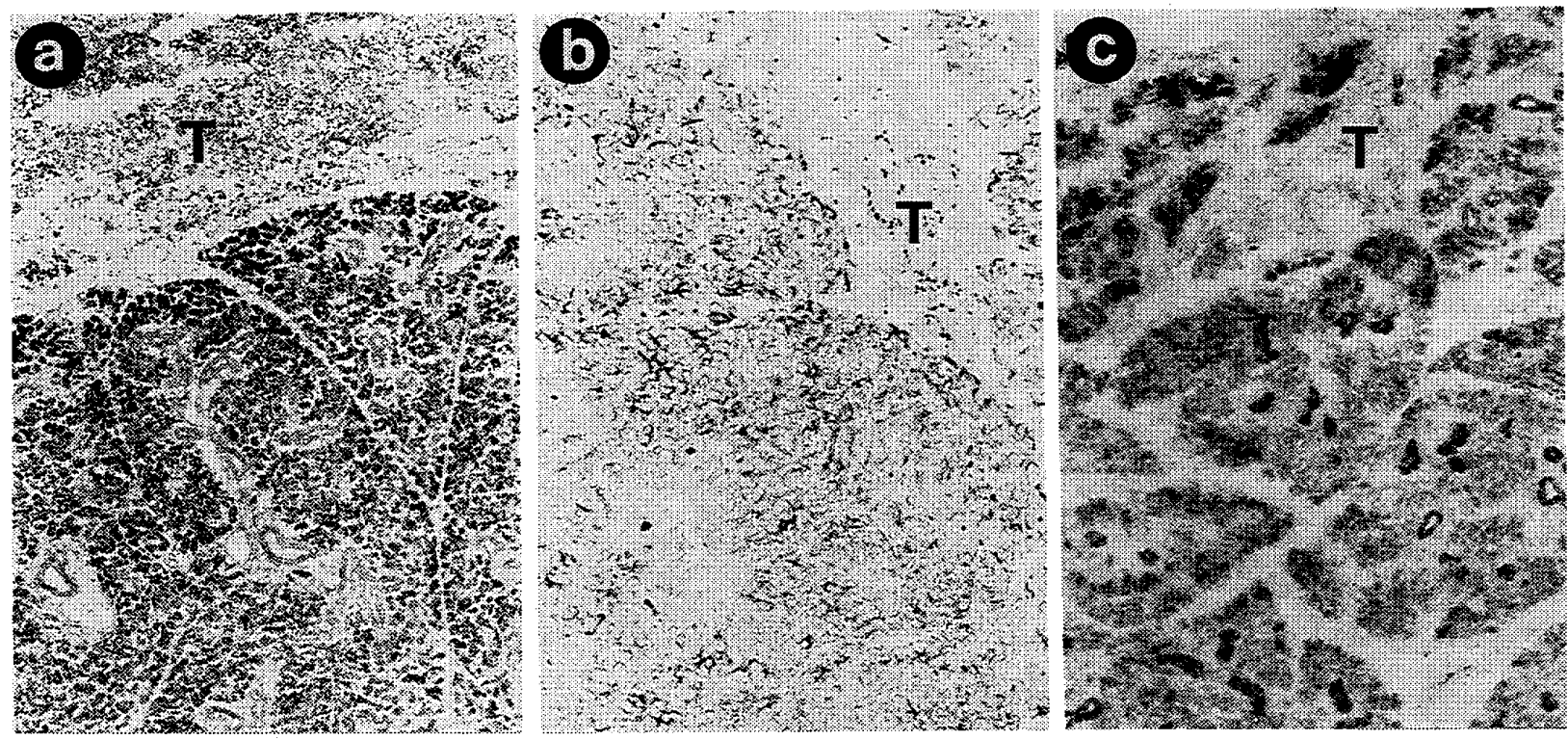

写真10 移植後 2 週例
a：ACP 反応（弱桩大），腫煌組織（ $\mathrm{T}$ ）と接する終末部腺房細胞では，強陽性に反応している．

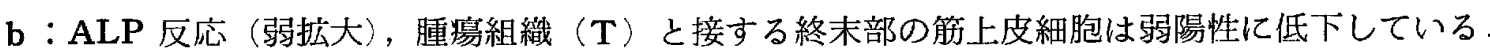

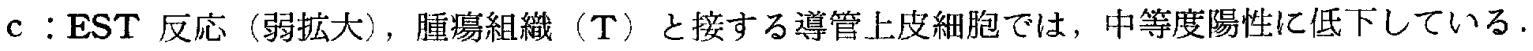

部において，組織学的に，炎症性細胞の浸潤がみられる 部にほぼ一致して，ALP 反応が強陽性となっている.

なお，腫煬組織から離れた部では，刘照例や移植後 1 週例之同様に, 終末部の筋上皮細胞の ALP 反応は強陽 を示している (写真 $10, \mathrm{~b})$.

EST 反応：増殖した腫煬組織の先端部では, 弱陽性 に反灾しているが，腫瘍組織てて囲繞された終末部の腺房 細胞は弱陽性, 介在部や線条部の導管上皮細胞は中等度 陽性となり，対照例に比べ EST 反応は低下している.

腫湟組織に接する終末部の腺房細胞では, 移植後 1 週 例と同样に, 対照例に比べ弱陽性で, 反応が低下してい る。また，介在部や線条部の導管上皮細胞でも同様に， 中等度の陽性と低下している。この EST 反态が低下し た部は移植後 1 週例に比へ，その範囲を増している。 な お，腫瘍組織から離れた部では，EST 反応は対照例や移 植後 1 週例之同様に変化は認められない(写真 $10, \mathrm{c}$ ).

\section{V. 移植後 3 週例}

\section{A. 組織学的所見}

$\mathrm{VX} 2$ 癌組織は移植後 2 週例に比べ, さらに浸潤し, 腺 体のほぼ $1 / 2$ から方までに增殖している

腫瘍先端に接する部では, 終末部腺房細胞や介在部お よび線条部の導管などが破壊され，腫煌組織に囲繞され た終末部の腺房細胞には強度の萎縮, 変形, 核の濃縮が みられる。また，介在部や線条部の導管上皮細胞も軽度

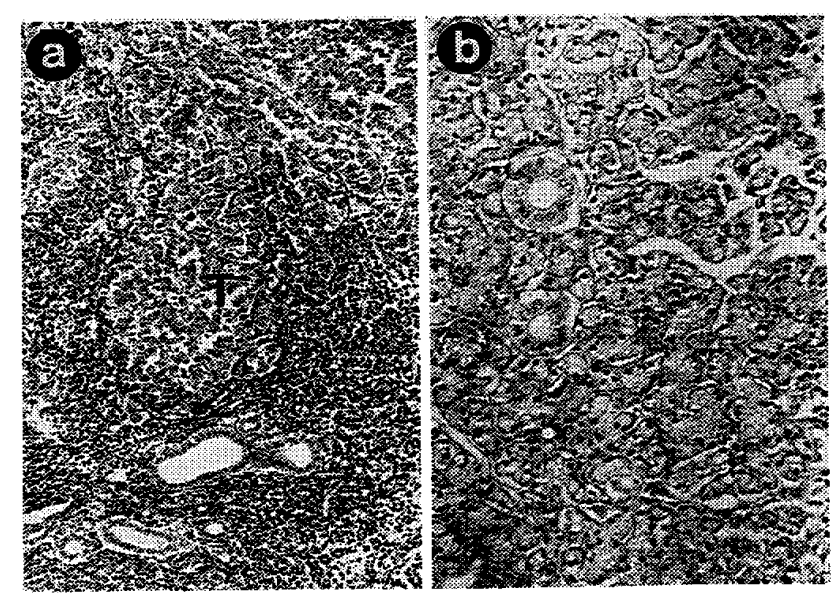

写真 11 移植後 3 週例

$\mathrm{a}: \mathrm{H} \cdot \mathrm{E}$ 染色, 弱拡大, $\mathrm{b}: \mathrm{PAS}$ 染色, 強扰大 腫煌組織（ $\mathrm{T}$ ) の周辺では, 導管上皮細胞の萎縮, 管腔の変形がみられ，著明な炎症性細胞の浸潤が認 められる。また，終末部腺房細胞では，PAS 晹性 物質が著明に減少している。

に萎縮し, 核が濃縮している.なお, 導管腔は腫場組織 に圧迫され, 狭窄し, 周囲の毛細血管では, 軽度の充血 と拡張が認められる。

腫崲組織に接した腺体部では, 移植後 2 週例でみられ た炎症性細胞の浸潤が，さらに広範团におよんでいる。 終末部の腺房細胞では, 移植後 2 週例に比へ, 細胞質に 
強度の萎縮, 変形が, 核でも濃縮や変形がかなり強く認 められる．また，てれにともないPAS 陽性物質も対照 例飞比へ，著しく減少している，一方，介在部や線条部 の導管上皮細胞では, 細胞質が軽度に萎縮し, 核では濃 縮，変形などがわずかにみられる．また，導管腔の拡張 や周囲毛紐血管での允血, 拡張が移植後 2 週例に比べ, さらに強度となり，その範囲も増している。

このような終末部腺房細胞や導管上皮細胞の細胞質に おける萎繀, 変形, 核の濃縮, 変形などの退行性変化は 腫煬組織に近接する部位で，とくに強度にみられたが， 腫湯組織から離れるにしたがい徐々に軽減している。な お，移植後 2 週例に比べ，その範囲をさらに増している (写真11).

\section{B . 醉素組織化学的所見}

$\mathrm{SDH}$ 反応：腫瘍組織の先端部では, 痕跡程度の反応 であったが，腫湟組織に囲繞された終末部腺房細胞でも 痕跡程度の反忍で, 腫瘍組織との差は認められない，ま た, 介在部や線条部の導管上皮紐胞も弱陽性で, 対照例 に扔ける SDH 反态と比べ著しく低下している。

腫煌組織に接する終末部の腺房細胞は全般にわたって 弱陽性で, 対照例に比べ反応は著しく弱く, 移植後 1 週,
2 週例に比へ，さらに低下している，とくに，腫煌組織 に直接接している部では，反応が著しく低下している. また，介在部や線条部の導管上皮細胞では，SDH 反応 が弱陽性で, 対照例と比べ著しく低下し, 移植後 2 週例 よりもさらに低下している．乙のように移植後 3 週例で は, SDH 反応が移植後 1 週, 2 週例に比べ, さらに低 下し，広範囲におよんでいる。しかしながら，腫煬組織 から離れるにしたがい，SDH 反応は徐々に強くなって いる。

以上のように，SDH 反応が低下している部では，組 織学的に, 終末部の腺房細胞および介在部や線条部での 細胞質の萎縮, 変形, 核の濃縮などの退行性変化がみら れる部とほぼ一致している (写真 $12, a)$.

$\mathrm{LDH}$ 反心：腫場組織の先端部では, LDH 反応は中 等度陽性を示しているが，腫晹組織に用繞された終末部 腺房細胞では, 反応が痕跡程度で, 対照例仁比べ,著しく 低下している．また，腫場組織に囲繞された介在部や線 条部の導管上皮細胞では, LDH 反応は中等度陽性で， 対照例に比べわずかに低下している.

腫湯組織に接する 終末部腺房細胞の LDH 反応は移植 後 2 週例之同様に弱陽性で，対照例に比べ低下してい
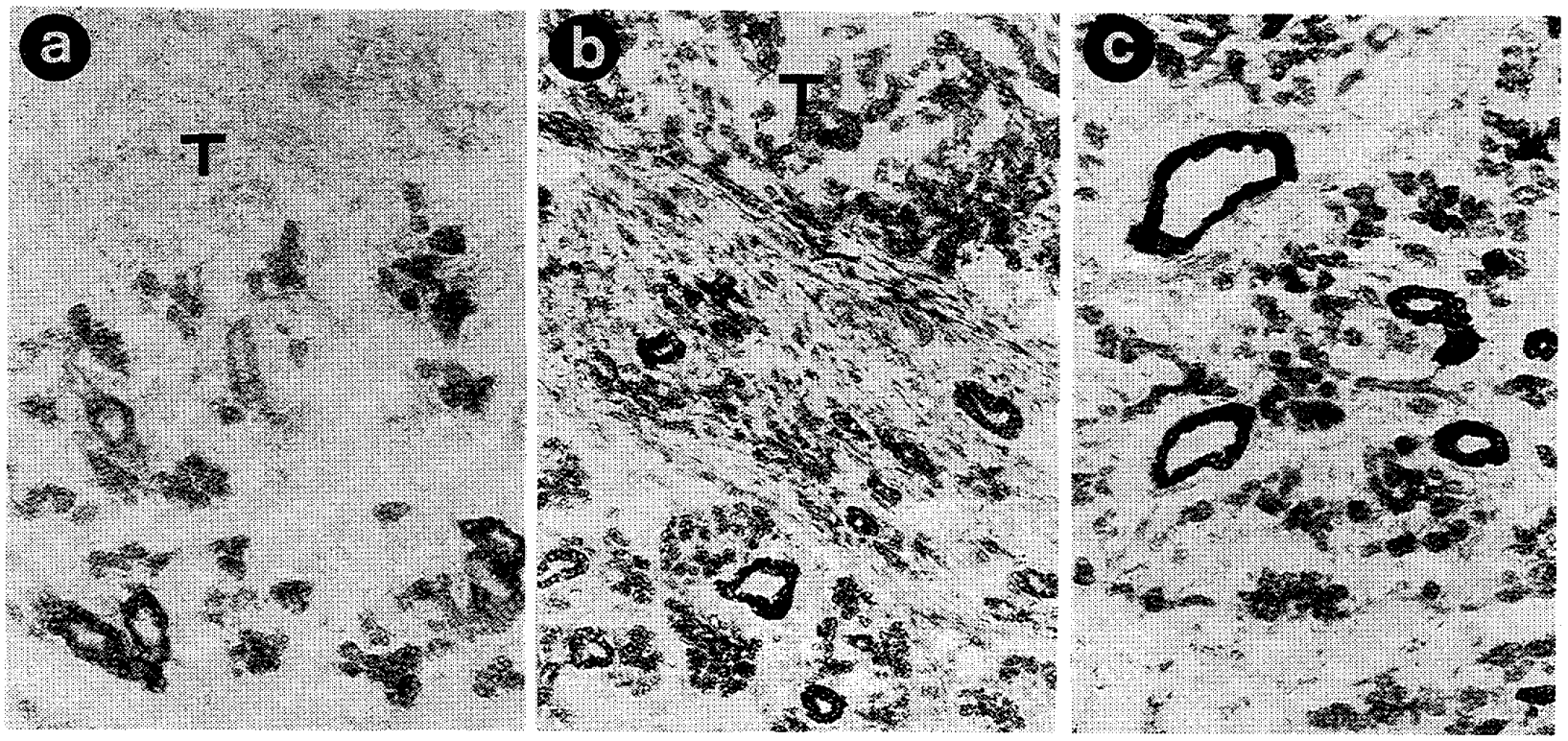

写真12 移植後 3 週例

$a ： S D H$ 反応（強拡大），腫煌組織（ $\mathrm{T} ）$ と直接接する終末部腺房細胞，導管上皮細胞は対照例に 比べ著しく低下している。

$\mathrm{b} ： \mathrm{LDH}$ 反灾 (強拡大), 腫瘍組織（T）と面接接する 終末部腺房細胞は弱陽性ないしは痕跡程 度，導管上皮細胞は中等度陽性にそれぞれ低下している。

c : LDH 反応 (強拡大), 腫瘍組織から離れた部で, 終末部腺房細胞は中等度陽性で軽度に低下し ている。 
る：腫煌組織に直接接する部でも, 弱陽性ないし痕跡程 度の LDH 反応を示し, 対照例に比べ著しく低下してい る.また, 介在部や線条部の導管上皮細胞の LDH 反応 は強陽性ないし中等度陽性で, 対照例, 移植後 1 週, 2 週例に比べ，いくぶん反応が低下している．てのような LDH 反志の低下は腫煬組織に接する腺体部で最も著し く, 腫焬組織から離れるにしたがって, 徐々にその反応 は強くなっている．また，その範囲は移植後 2 週例より もさらに広範用となり, 腺体辺縁部の一部を残すのみと なっている、おな，LDH 反応が低下している部は組織 学的に, 終末部腺房細胞および介在部や線条部の導管上 皮細胞における細胞質の萎縮, 変形, 核の濃縮などの退 行性変化がみられる部とほぼ一致している（写真12, b , c).

$\mathrm{ACP}$ 反応 : 痕跡程度に反応を示す腫瘍組織に 囲繞さ れた終末部の腺房細胞では, 強陽性で, 対照例に比べそ の反応は強く，乙れに反し介在部や線条部の導管上皮細 胞では, 痕跡程度の ACP 反応がみられ，対照例に比べ その反応は低下している。

腫場組織に接する終末部の腺房細胞は中等度ないしは 強陽性に反応し, 移植後 2 週例とほほ同程度である。ま
た，腫瘍組織に直接接する部では，強陽性の ACP 反応 がみられ，対照例に比べ強度である。しかしながら，腫 瘍組織から離れるにしたがい，ACP 反心は徐々に低下 し, 対照例, 移植後 1 週, 2 週例でみられた中等度陽性 とほほ同様な反応である，一方，介在部や線条部の導管 上皮細胞では，全般的に対照例と同様な弱陽性の $\mathrm{ACP}$ 反応を示しているが，とくに腫煌組織に近接あるいは直 接接する部では, 痕跡程度の反応で, 低下している（写 真13, a ).

ALP 反応：終末部腺房細胞，介在部および線条部の 導管上皮細胞は対照例，移植後 1 週， 2 週例と同様に， 腺体全般にわたって ALP 反応は認められない。しかし ながら，腫瘍組織に囲繞された終末部の筋上皮細胞は弱 陽性ないしは痕跡程度の ALP 反応を示し，対照例にお ける終末部の筋上皮細胞の反応に比べて，著しく低下し ている，一方，腫煌組織に接する終末部の筋上皮細胞は ALP 反応が弱陽性で, 移植後 2 週例 と同程度である が，その範囲はさらに広くなっている．また，腫煬組織 から離れるにしたがい，ALP 反応は徐々に強くなり， 腺体辺縁部では強陽性で，対照例と同程度である。な お，乙の部では組織学的に炎症性細胞浸潤が強く，强陽
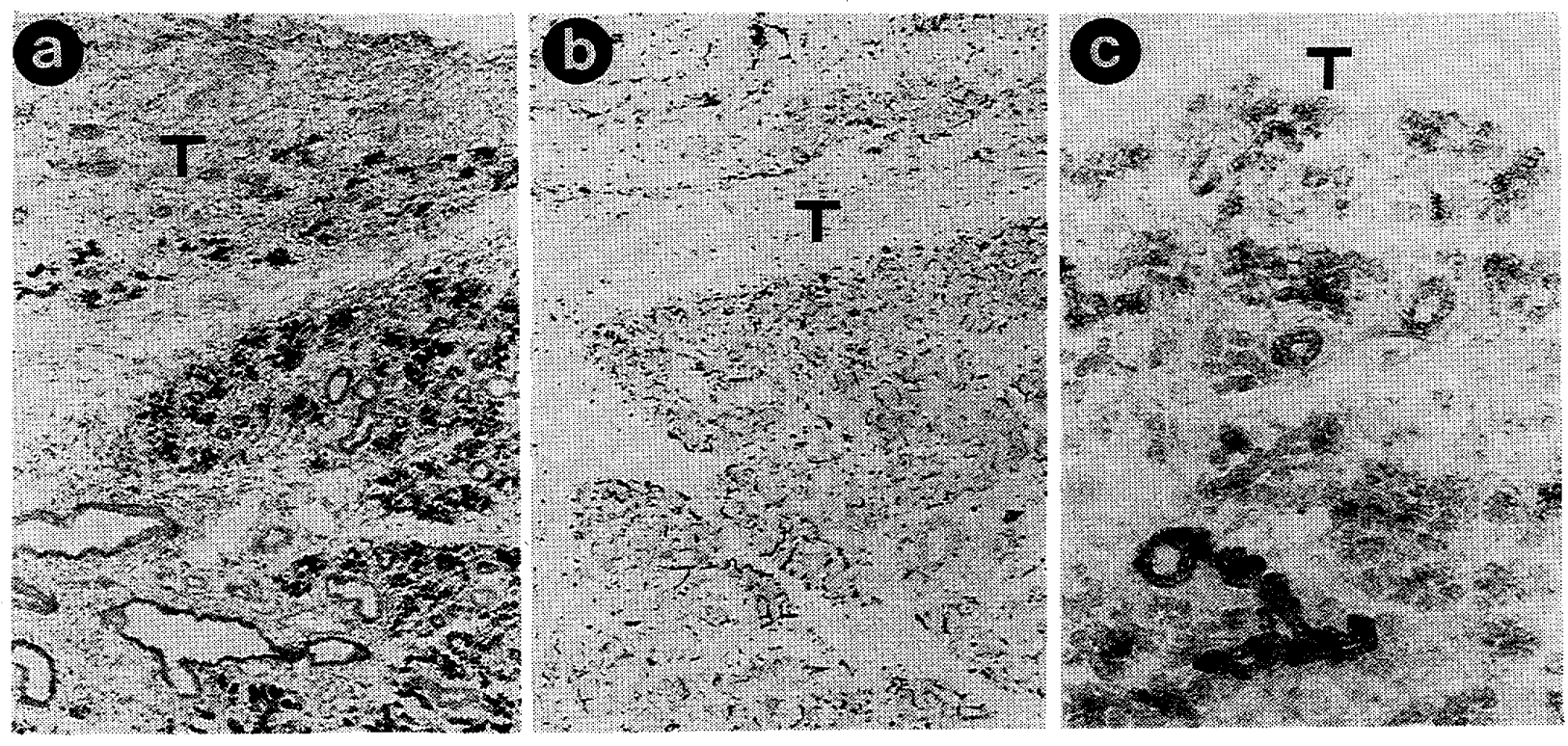

写真13 移植後 3 週例

$\mathrm{a} ： \mathrm{ACP}$ 反応（弱拡大），腫湯組織（T）に囲繞された部または接した部の終末部腺房細胞は強陽 性に反応している。

b : ALP 反応（弱拡大），腫瘍組織（T）と接する終末部の筋上皮細胞は弱陽性に低下している. また，炎症性細胞浸潤とほぼ一致して強陽性反応が認められる。

c : EST 反応 (強拡大), 腫瘍組織 $(\mathrm{T})$ と接する終末部腺房細胞は弱陽性，導管上皮細胞は中等 度陽性にそれぞれ低下している。 
性反心を示す部と一致している（写真13，b）.

EST 反忘：腫痬組織の先端部は弱陽性であるが, 腫 塲組織に囲絓された終末部の腺房細胞は痕跡程度に反応 し，刘照例に比べ著しく低下している．しかしながら， 介在部や線条部の導管上皮細胞では, 中等度の反応がみ られ, 移植後 2 週例と同様に, 対照例に比べ低下してい る。

腫煌組織に接する部から腺体辺縁部までは EST 反灾 は全般的に弱陽性で, 刘照例に比べ軽度の低下がみられ る、また，腫瘍組織に直接接する部で，その反応は痕跡 程度で，対照例に比へ，著しく低下している。さらに， 移植後 1 週, 2 週例に比へ，反志はいくぶん低下してお り，その範用も広くなっている。一方, 介在部や線条部 の導管上皮細胞では，とくに，腫煬組織に臬接接する部 で, EST 反応は中等度陽性と低下しているが,他の部で は，移植後 1 週， 2 週例とほほ同程度である。なお， EST 反応が低下している範囲は組織学的に, 終末部腺 房細胞および介在部や線条部の導管上皮細胞における細 胞質の萎縮, 翌形, 核の濃縮などの退行性変化の示す部 とほぼ一致している（写真13, c).

V. 移植後 4 週例

A. 組織学的所見

$\mathrm{VX} 2$ 癌組織は移植後 3 週例に比べ, きらに浸潤し, 顎 下腺のほぼ出程度を占めるまでに増殖している。したが って，顎下腺組織はわずか化残っているにすぎない。

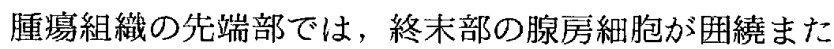
は破壊され，团繞された終末部の腺房細胞は著しく萎 縮, 変形し, 融解もみられる. 核では濃縮, 変形, 融解, 消失しものが多くみられる，腫瘍組織に囲繞された介在 部や線条部の導管上皮細胞は強度に萎縮し, 核も濃縮, 変形している．また，導管腔は著しく狭小化している。

な抢，残存した顎下腺組織内には，全般的に炎症性細 胞の浸潤が中等度にみられ，終末部の腺房細胞は著しく 萎縮, 変形し，核も濃縮している。また，PAS 陽性物 質も著しく減少し，わずか代散見されるにすぎない．

一方，介在部や線条部の導管上皮細胞では，終末部腺 序細胞でみられたような退行性変化はなく，移植後 3 週 例之同椂に，介在部や線条部の導管上皮細胞の萎縮，核 の濃縮が軽度にみられ，導管腔の拡張さらには導管周囲 の毛紐血管で，中等度の充血と拡張がみられる。

以上のような所兒は残存顎下腺組織の全般にわたって みられるが，とくに，腫踼組織に直接に接する部では強 度である（写真14）。

B. 䤏素組織化学的所見

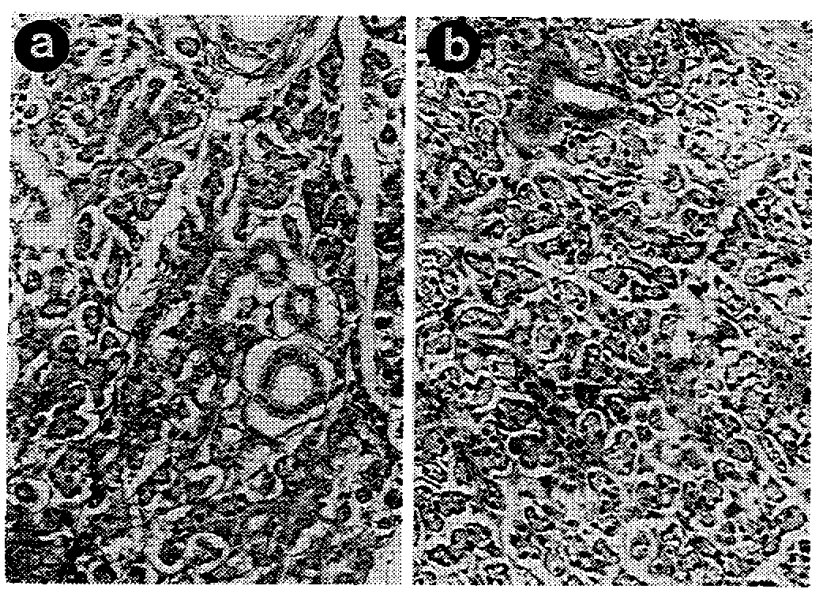

写真 14 移植後 4 週例

$\mathrm{a}: \mathrm{H} \cdot \mathrm{E}$ 染色, 強拡大, $\mathrm{b}: \mathrm{PAS}$ 染色, 強拡大 終末部の腺房細胞は強度の退行性変化を示し, PAS 陽性物質も著明に減少している。

$\mathrm{SDH}$ 反応：腫焬組織に囲繞された終末部の腺房細胞 では, 陰性ないしは痕跡程度の反応で, 対照例と比べ, 反心は著しく低下している．また，介在部や線条部の導 管上皮紐胞は弱陽性で，対照例に比べ反応は低下してい る。

残存した䖀下腺の終末部腺房細胞は全般的に痕跡程度 のSDH 反応を示し, 対照例に比べ著しく低下してい る.とくに, 腫煌組織と直接に接する部では, 終末部腺 房細胞に SDH 反応が認められないものが多数みられ る。一方，介在部や線条部の導管上皮細胞は全般的に中 等の $\mathrm{SDH}$ 反応を示し, 対照例や移植後 1 週, 2 週, 3 週例と比べ，さらに低下しているが，とくに，腫瘍組織 と直接に接する部での SDH 反心は弱陽性で，対照例に 比べ著しく低下している（写真15，a）.

$\mathrm{LDH}$ 反応：腫瘍組織に囲繞された終末部の腺房細胞 は対照例に比へ，反応は著しく低下し，陰性ないしは痕 跡程度の反応である，また，介在部や線条部の導管上皮 細胞でも対照例と比べ，LDH 反応が低下し，中等度陽 性である。

残存した顎下腺終末部の腺房細胞は全般的に弱陽性の LDH 反応であるが，対照例と比べ著しく低下している. また, 移植後 3 週例に比べ, さらに反応が低下し，腫瘍 組織と直接に接する部では, 痕跡程度へと反応が低下し ているものも認められる。一方，介在部や線条部の導管 上皮細胞では，LDH 反応の低下は軽度で, 腫瘍組織と 直接に接する部でも反応は低下しているが，中等度陽性 である

以上のように LDH 反応の低下は終末部腺房細胞およ 
び介在部や線条部における細胞質の菱縮や変形，核の濃 縮をはじめとする退行性変化とほぼ一致しているが，導 管上皮細胞に抢ける LDH 反応の低下は, 組織学的な退 行性変化に比べ軽度である（写真 $15, b)$ ）。

ACP 反応：腫煌組織に囲繞された終末部の腺房細胞 は中等度陽性ないし弱陽性の反态で, 対照例と比べ著し く低下している。.また，介在部や線条部の導管上皮細胞 でも痕跡程度の反応である。

残存した終末部腺房細胞の ACP 反応け全般的に中等 度陽性で, 対照例とさほどの変化は認められないが, 腫 瘍組織に直接に接する部では, 強陽性の ACP 反応を示 すものが多くみられる，一方，介在部や線条部の導管上 皮細胞では，全般的に対照例とほぼ同程度の ACP 反応 である.なお，移植後 3 週例と同様に腫值組織と直接に 接する部では痕跡程度の反応である (写直 $15, \mathrm{c}$ ).

ALP 反応：残存顎下組織の 終末部腺房細胞および介 在部や線条部の導管上皮細胞では, ALP 反応は全く認 められない。

腫湯組織に囲繞された終末部の筋上皮細胞では，対照 例に比べ，反応が著しく低下し，朖跡程度の反応であ る.一方，残存した顎下腺組織の終末部における筋上皮
細胞は, 全般的に弱陽性で, 対照例に比べ著しく低下し ている，とくに，腫瘍組織と直接に接する部では，痕跡 程度の反応である。な抢, 組織学的に, 炎症性細胞の浸 潤の程度にほほ一致して, 強陽性ないしは中等度陽性に 反応がみられる(写直16，a）。

EST 反応：腫瘍組織に 团繞された終末部の腺房細胞 は陰性もしくは痕跡程度で，介在部や線条部の導管上皮 紐胞でも痕跡程度または弱陽性とそれぞれ対照例に比 べ，EST 反応は低下している。

残存した顎下腺組織の終末部腺房細胞は全般的に痕跡 程度の反応で低下し, 移植後 3 週例よりもさらに反応は 低下している。また，腫煌組織と直接に接する部では， EST 反応が認められないところもみられる，一方，介 在部や線条部の導管上皮細胞でも全般的に EST 反応は 弱陽性で，対照例に比べ著しく低下している．また，移 植後 3 週例に比へさらに低下している(写直 $16, b ， \mathrm{c}$ ).

\section{総括ならびに考察}

悪性腫瘍の治療は早期診断，早期治療が最善とされて おり10,19,47)，口腔癌の治療についても論をまたない。 しかしながら, 口腔癌が比較的早期に, 周囲軟組織や顎
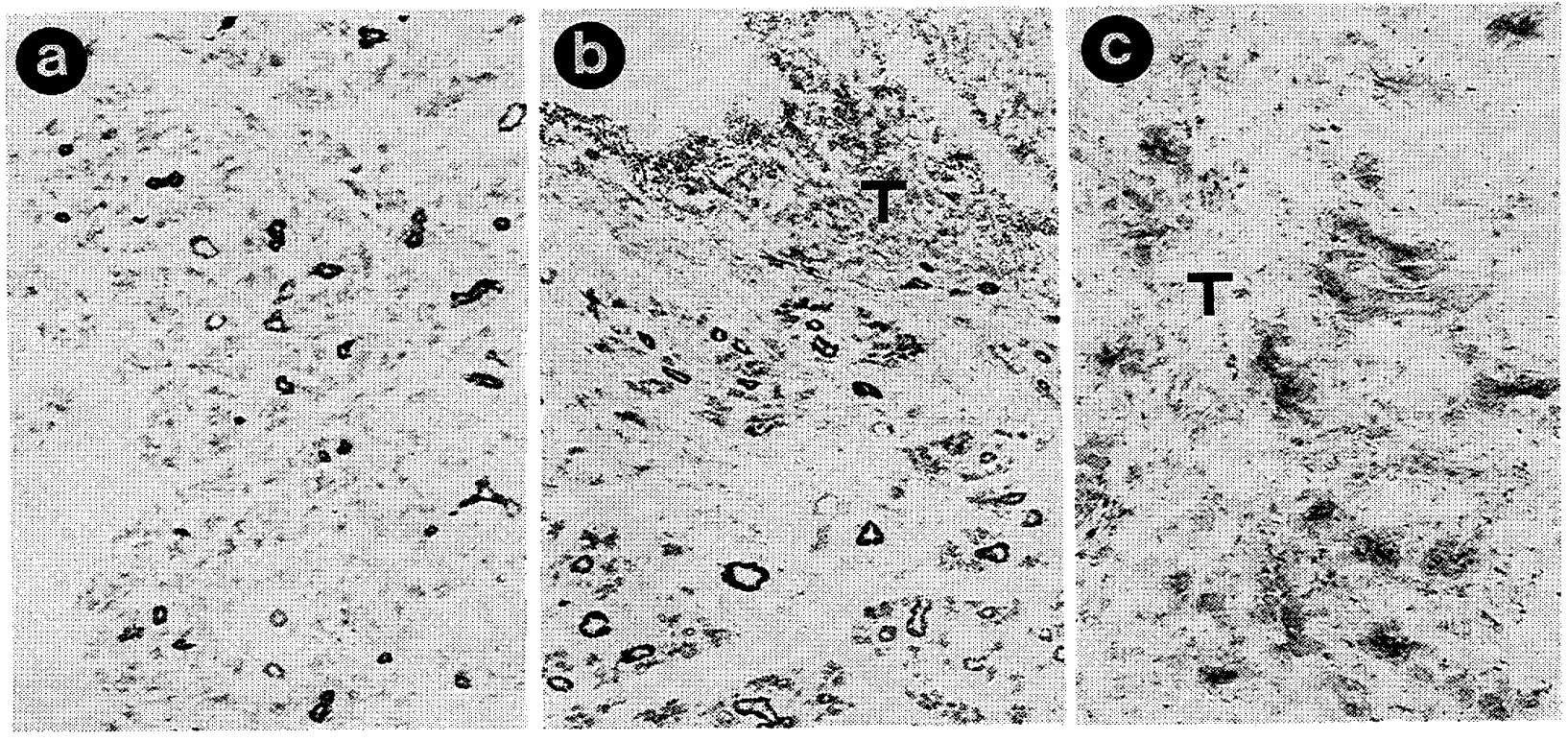

写真15

移植後 4 週例

a : SDH 反応 (弱拡大)，全般的に終末部腺房細胞は痕跡程度，導管上皮細胞は中等度陽性で， 対照例に比べ著しく低下している.

b：LDH 反志（弱拡大，，全般的に終末部腺房細胞は弱陽性に低下しているが，導管上皮細胞で は，反応の低下は軽度である( $\mathrm{T} ：$ 腫煬組織)。

c：ACP 反応 (強拡大), 腫瘍組織（ $\mathrm{T}$ ）に困繞された終末部腺抟細胞は弱陽性，導管上皮細胞は 痕跡程度にそれぞれ低下している。 

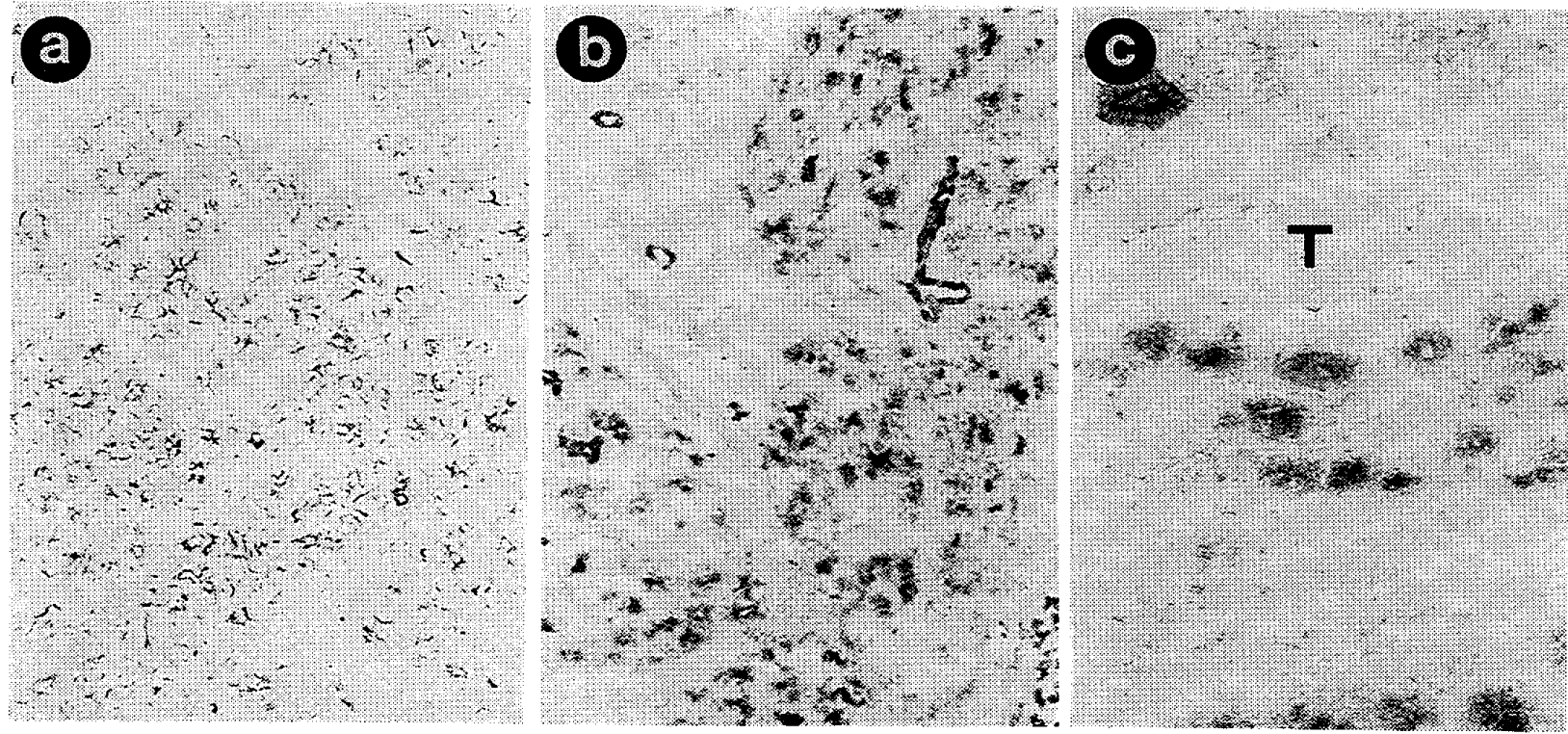

写真16 移植後 4 週例

a：ALP 反応（弱拡大），全般的に終末部の筋上皮細胞は弱陽性で, 対照例に比べ著しく低下して いる。

b : EST 反応 (弱拡大), 全般的に終末部腺房細胞は痕跡程度, 導管上皮細胞は弱陽性で, 対照例 に比べ著しく低下している。

c：EST 反応(強拡大，腫㾔組織（T）に囲繞された導管上皮細胞は痕跡程度にまで低下してい る.

骨を浸潤するととは周知のことである ${ }^{1-8)}$ 。とくに，顎 ・ 口腔領域では菌肉, 煩, 舌, 顎骨, 垂液腺など, それ ぞれ解剖学的, 組織学的に異なった構造を呈しているた め, その浸潤, 発育様式も多種多様である ${ }^{3-111}$ 。一方, 口腔という特殊性から，治療後における形態および機能 の保持という重要な問題が残され，治療後の障害をでき うるだけ回避した適切なる治療法が望まれる。したがっ $\tau$, 早期に発見し, 外科的療法, 放射線療法, 化学療法 を組合せた集学的治療が夷施されているのが現状であ $3^{12-201}$. より効果的な治䕩を実施するためには口腔癌 の増殖態度や，それに対灾する正常組織の変化につい て,十分な把握が肝要である。ちなみに，Jakobsson ら

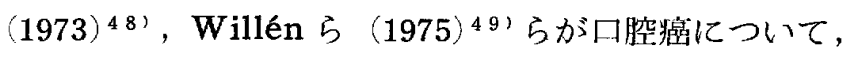
腫演実質因子のみならず，腫徬周辺部における腫煬一宿 主関連因子をも十分に考慮した検討の必要性を示唆して いる.

このような観点から，てれまでに曰腔癌モデルを用い た研究が種々と報告されているが，乙れらの研究はおお むね発癌物質を用いた研究21,23-26,29,31,33-35,37) と 移植腫瘍を用いた研究 $22,27,28,30,32,36,38-40)$ 之に大 別される、このうち, 唾液腺と腫煬に関する研究では,
発癌物質や移植腫瘍を用いた病理組織学的な研究 21ー24, $27,29,31-35,37,39)$ が主で, 刘応する唾液腺組織の変化 を酵素組織化学的に検索した 報告は少なく，わずかに Sugimura ら $(1966)^{25}$ がマウス耳下腺で, Matsumura

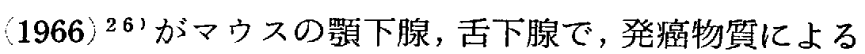
研究をみるにすぎない，また，唾液腺へ可移植性腫啺を 移植し，増殖状況を研究したものとしては島田（1960） ${ }^{22)}$ ，川勝ら $(1969)^{27)}$, 中村 $(1984)^{39}$ らの報告が散 見されるが, 増殖にともなう唾液腺組織の対応を酵素組 織化学的に検索した報告は著者の渉猟しえた範囲内では 見当らない，そこで，著者は正常家鬼の顎下腺に，ヒ卜 の口腔癌で最も多い扁平上皮癌に類似した組織型を有す るVX2癌30,39-42) を移植し, 腫煌の増殖にともなう箩 下腚組織の態度を病理組織学的ならびに酵素組織化学的 に検索した。

本実験に使用した VX2舅は Rous ら（1940４2）によ って確立された可移植性腫婸41つで, 当教室において累 代移植されているものである.

研究の対象とした醉素は酸化還元䤃素として SDH, $\mathrm{LDH}$ を, また, 加水分解醉素として ACP, ALP, EST である。乙れらの酵素は細胞の生物活性にきわめ 
て深い関係をもつ酵素で, その局在性や消長等を検索す ることは，睡液腺における腺分泌ならびに各細胞で行わ れている種々な代謝機構の一端を知り得るものとされて (る50-53).

SDH，LDH はともに酸化環元醭素として，それぞれ 好気的あるいは嫌気的エネルギー代謝に関与し50,52， 54)，とくに SDH はミトコンドリアの標識酥素とされ ている50,51,53ー61). 正常家鬼唾液腺におけるSDH 反 応は, 終末部の腺房細胞では, 弱陽性ないし中等度陽性 に，導管上皮細胞で，強陽性反応を示すとされている ${ }^{51 ，}$ $52,55,57,60,611$. また，LDH 反応は，終末部の腺房細 胞，導管上皮細胞ともに強陽性反応を示すことも知られ ている51,52)。乙れらの知見は本実験における対照例で の所見と一致していた。

これまでの睡液腺を対象とした酵素反念の研究には， ラット, イヌ, 家兔などで耳下腺, 顎下腺, 舌下腺など の排泄管の結紮実験や流出障害に関する実験が多い50， $51,53,54,59,621$. 芝 $(1967)^{501}$ はラット顎下腺および 舌下腺の排出管を結紮し, 終末部腺房細胞の萎縮や, 導 管の拡張を認め，その変化に対応して SDH 反応も漸次 低下していたが，とくに拡張した導管で著明であったと 報告している，園部 $(1978)^{51}$ は家兄耳下腺の排泄管結 紮による $\mathrm{SDH}, \mathrm{LDH}, \mathrm{ACP}$ 反応の変化を検索し, 結 禁後 7 日目より終末部腺房細胞の萎縮, 腺腔の拡張, 導 管の拡張なぞを認め, 腺腔に拡張がみられる小葉辺縁部 で SDH，LDH 反応がとくに低下していたと報告して いる．また，橋本 $(1986)^{54)}$ はイ又顎下腺に流出障害を 起こさせ, 終末部腺房細胞の萎縮や, 抎張した導管で, $\mathrm{SDH}, \mathrm{LDH}$ 反応が低下したと報告している。ささに， 黒川 $(1982)^{52}$ は家鬼耳下腺におよほすす制癌凪の影響を 検索し,組織学的な退行性変化䎲ともない, SDH, LDH 反応の低下を報告し，機能低下を示唆している，以上の ような諸家の報告50-52,54)では，組織学的な退行性変 化と SDH, LDH 反応の低下, さらに機能の低下とい う面で一致している。

本実験では，移植腫煌の浸潤，増殖にともなう顎下腺 組織の変化を病理組織学的, 酵素組織化学的に検索した が，腫煌組織に囲繞された部や直接接する部の顎下腺 組織では, 終末部腺房細胞で増殖にともない経週的に $\mathrm{SDH}, \mathrm{LDH}$ 反応が低下したのに刘し, 介在部や線条部 の導管上皮細胞では，SDH，LDH 反忘は軽度な低下で あったが，対照例や腫煌組織から離れた部に比べ，かな り低下していた，以上の上うな導管上皮細胞における両 反応の低下については，芝 $\left.(1967)^{50}\right)^{\prime}$ が排出管結禁実験
より，導管上皮細胞は内腔から圧迫を受け，ミトコンド リアの配列不整や柾散がみられ，ミトコンドリアを代謝 の場とする酸化醉素の障害によると報告している．ま た，橋本 $(1986)^{54)}$ も流出障害により分泌液過剩となり， 終末部腺房や導管に水分が堌加し, 酸素供給が不足する ため，ミトコンドリアに膨化をきたし，SDH 反応が低 下したと報告している．

本実験に打ける導管上皮細胞の SDH 反态の低下は実 験方法にもよるが, 組織学的に, 腫䀛組織が直接に導管 上皮細胞を浸潤，増殖していなかったてとから，排渵管 結禁による流出障害に起因するほどの著明な低下は認め られないものの, 腫演組織から離れた部の反応, 対照例 の反応などから考慮すれば，過剩分泌による影響も十分 考えられる。また，終末部腺房細胞に比べ，導管上皮細 胞の構造上の抵抗性などもその一因とした差異とも考え られる。 ちなみに, 试田ら $(1981)^{631}$ の睡液腺の変性お よび破壊機転に対し, 終末部腺房細胞の強い抵抗性を指 摘した報告もみられる：また，中村 $(1984)^{39 ｝ \text { もVX2 }$ 癌組織の漫潤に対する導管上皮細胞の抵抗性を報告して いる.

一方, 終末部腺房細胞における SDH, LDH 反応の 低下については, 本実験では, 組織学的な構造上の問 題, さらには分泌物の野留による代謝機能の障害も否定 できないが, 腫踼組織に用繞された部, 直接接した部, PAS 陽性物質が減少した部さらに 遠隔の 健康部などの 所見から, 腫煬組織の終末部腺房細胞への浸潤, 破壊に よるものと考えられる. このととは, 移植後 4 週例で は, 腫崲組織の浸潤, 増殖により唾液腺組織はほとんど 破壊され，壊死となり，わずかに残すのみとなっていた が，SDH，LDH 反応が著しく低下していたてとより， 腫煌組織の直接的影響と考えられる。

一方, 加水分解醉素としての $\mathrm{ACP}, \mathrm{ALP}, \mathrm{EST} は$ 細胞の代謝機構に重要な酵素である．とくに，ACP は ライソゾームの標識醉素とされている51,53,54,64-68). 正常家鬼㳘液腺における ACP 反态の検索では, 終末部 腺房細胞で強陽性反応を示し, 導管上皮細胞は中等度 ないしは弱陽性反応を示すと報告されている ${ }^{51,60,69}$ ， 701。また，ALP 反応については筋上皮細胞で強陽性反 応がみられ，終末部腚房細胞や導管上皮細胞では，全く 反応が示さ机ないことも報告されている60,61,71,721 さ らに EST 反応は導管上皮細胞にきわめて強い反応を示 すが，終末部腺房細胞では，中等度の陽性反応といわれ ている61,70)。乙れらの所見は，本実験でも対照例の $\mathrm{ACP}, \mathrm{ALP}, \mathrm{EST}$ 反応沈いて, 同様な所見であっ 
た、ACP 反忍の変化について，園部(1978 ${ }^{51) は 耳 下 ~}$ 腺の排泄管結禁実験で，終末部腺房細胞では，反応の低 下がみられたが，導管上皮細胞では，結禁期間が長期に わたっても反心の低下は認められなかったと報告してい

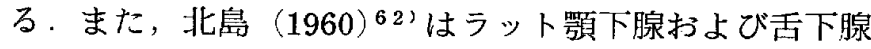
の排出管の結禁で，終末部腺房細胞の ACP 反応の著明 な低下を報告している，さらに，浅野 $(1986)^{53}$ も 卜顎下腺導管を結紮したところ，終末部腺房細胞や線条 部の導管上皮細胞で，ACP 反応が低下あるいは消失し たと報告している．しかしながら，橋本（1986）54はイ 又顎下腺で流出障害を起こさせ，導管上皮細胞では，し だいに ACP 反応は低下したが，終末部腺房細胞では， いったん反忍は低下したものの，再び反応の上昇を誌 め, とくに, 変性, 萎縮, 壊死のみられる部にきわめて 強いACP 反応がみられたと報告している，さらに橋本 (1986) ${ }^{54}$ 'は反忘の低下の原因について, 流出障害では, 排泄管の閉塞が完全でないため，少量の唾液の流出を認 め，そのため，いったん減少した反心が再び細胞の生活 力を増し，一時的に反応が元進したためではないかと報 告している.

本実験では, 終末部腺房細胞の萎縮, 変形がみられる 部で，強陽性反応がみられたことから，橋本(1986)54) の報告と一致する。しかしながら，本実験では，とく に，腫焬組織に囲繞された部や，腫焬組織と直接接して いる部で，しかも萎縮，変形などが強度で，PAS 陽性 物質が減少した部において反応が強いととから，終末部 腺房細胞の生活力が増したとは考えられない。また， ACP がライソゾームの標識酵素であることから51,53, 54,64-68)，ライソゾームの機能について，倉橋（1970） 66) は細胞内における外来異物の消化作用と, 不要化し た細胞質の部分的自己消化を報告している。さらに，本 川 $(1978)^{67}$ 6変性した味藍細胞内に強い ACP 反応を 認め, 変性した味薔細胞内には, 不要化した細胞小器官 を吸収除去するための自己消化の役割をもつライソゾー 么の増加を指摘し，倉橋 $(1970)^{66)}$ と同様な罗解を報告 している。したがって，本责験におけるACP 反忘の増 強は腫煬組織の増殖により，終末部腺房細胞が強度の退 行性変化を起こして, 破壊され, 倉橋 $(1970)^{66)}$, 本川 (1978) ${ }^{67)}$ らの見解，すなわち細胞内に打ける自己消化 のためのライソゾームの増加と考元られる。なお，移植 後 4 週例では, 腫锡組織に囲繞された終末部腺房綀胞 で，反応の低下が認められたが，乙れはライソゾームが 不要化となった細胞小器官を完全に自己消化した結果に もとづくもので, 対照例とほぼ同程度にまで低下したと
考えられる。一方，導管部における ACP 反応について は, 園部 $(1978)^{51}$ 'が耳下腺排泄管結禁後, 徐々に増強 したと報告しているが，浅野（1986） ${ }^{53}$ 'は結禁後，1日 目で線条部導管上皮細胞の反応は完全に消失したとい い，橋本 $(1986)^{54)}$ も流出障害を起こさせた後，しだい に反応は低下したと報告している，このように，導管上 皮細胞における ACP 反応の所見には異なった見解がみ られる，本実験では，腫瘍組織に囲繞された部や，腫崲 組織と直接接した部の導管上皮細胞では，軽度な反応の 低下がみられた。なお，との部位では，組織学的に導管 上皮細胞に，腫瘍組織による直接の浸潤，増殖がみられ ないことから，導管上皮細胞の抵抗性 ${ }^{39,63)}$ などを考虑 すれば，導管上皮細胞では，ライソゾームによる自己消 化といらよりはむしろ退行性変化にともなう機能減退に よるライソゾームの減少が，反応の低下に関与している ものではなかろうかと推察される。

加水分解酵素である ALP， EST の変化については， 北島 $(1960)^{62}$ 'がラット顎下腺, 舌下腺の排出管結禁後, 終末部腺房細胞は 2 日目には萎縮, 壊死を起こし，それ にともなって，終末部の筋上皮細胞の ALP 反応，腺房 細胞の EST 反応が著明に減弱したと報告している。 ま た，浅野 $(1986)^{53)}$ もラット龥下腺導管結禁後， $3 \sim 6$ 時間で筋上皮紐胞の ALP 反応は急速に低下し，結禁後 1 日目で反応ははとんど消失していたと報告している。 しかしながら，芝 $(1967)^{50 \prime}$ はラット䫟下腺および舌下 腺の排出管結紮後, 終朱部腺房細胞が明らかに縮小し, 筋上皮細胞の網眼状棈造は不明瞭となったが，ALP 反 志に低下をみなかったと報告している，また，橋本（19 86 54) も流出障害を起こさせた後では，觔上皮細胞には 罗少の変動がみられるものの, 強い反応を維持していた と報告している．本夷験では，腫瘍組織に国繞された部 や，直接接した終末部では，筋上皮細胞における ALP 反応および腺房細胞での EST 反応は経䓢的に反忘が低 下し，さらに同部の導管上皮細胞でも EST 反応が経週 的に低下していた。しかしながら，腫踼組織から離れた 部では，ALP，EST 反応ともにさほどの変化は㤠めら れなかった．ALP 反応の低下については，浅野（1986） $53)$ は尊管結紮によって, 筋上皮細胞の膜輸送機能に急 速な変化を生じたためと報告している，また，橋本（19 86） ${ }^{5{ }^{4}}$ は終末部腺房細胞の萎縮, 消失により㩖液分泌機 能の低下と密接な関係があると報告している。本実験で は，腫煬組織に囲繞または直接接している部で, 終末部 の筋上皮細胞に反応の低下がみられたととは，終末部腺 房細胞の萎縮により，筋上皮細胞の機能である分泌物を 
腺腔内人押し出す衝き50,54,58,64,71,73'が失われたた め，ALP 反応が低下したのではないかと考えられる。 なお゙,腫煬組織と離れた部では，終末部腺房細胞の萎縮 がさほどではないため，対照例と同様に比較的強い反心 がみられ，ALP 反忍が終末部腺房細胞と密接な関係を 有していることが示唆される。なお，本実験では，炎症 性細胞浸潤がみられる部にほぼ一致して ALP 反応がみ られたが，これは Monis ら (1960)74)，川勝ら（1963） ${ }^{75}$ ), 森 (1981 $)^{76)}$ らの見解と同様に, 多核白血球, と くに好中球に起因しているものと思われる.

EST 反応の低下は，北島 $(1960)^{62}$ 'が菱縮，壊死し た終末部腺房細胞で, 著明な反応の低下を認めており, 本実験でも退行性変化の強度な部, すなわち, 腫癔組織 に囲繞された部や，腫瘍組織と面接接し，PAS 陽性物 質の減少した終末部腺房細胞や同部の導管上皮細胞で, 経週的な反応の低下を認め，その範囲も増していた。し かしながら, 腫湯組織から離れた導管上皮細胞では, 比 較的強い反応が認められた。

EST の生理的, 機能的意義に関しては, まだけ分に は解明されていない面もあるが，その機能の一つとし て, 細胞内での物質の運搬作用77が挙げられている。 このことからすれば，本奏験における EST 反応の低下 は，腫陽組織に囲繞された部や，直接接し，PAS 陽性 物質の減少した終末部腺房細胞で著明であった。このこ とは，腫煬組織により，顎下腺組織が直接的な浸潤，破 壊を受け，細胞内での物質の運搬作用に影響をきたした ものと考えられる。また，導管上皮細胞でも腫瘍組織に 囲繞された部や，直接接した部では，反応が低下してい たが，腫瘍組織から離れた部では，比較的強い反忘が維 持されていることから, 導管上皮細胞の抵抗性 ${ }^{39,633}$ 亿 よるものと考えられる，てのように EST 反応は組織学 的な退行性変化々ほぼ一致して低下していた。

以上の実験成績を総括すれば， $\mathrm{VX} 2$ 癌組織の浸潤， 増殖は顎下腺組織に形態学的な退行性変化を引き起こす のみならず，分泌物質の合成，排泄などの機能的な面に まで影響を与えるものと考えられる。さらに，終末部の 腺房細胞や筋上皮細胞扝よび導管上皮細胞の酵素反応に 変化をきたし，額下腺組織の代謝機構にまで影響を与え るものと考えられる。

\section{結}

\section{論}

著者は家灾の顎下腺に VX2 癌を移植し, 腫瘍の増殖 にともなう顎下腺組織の態度を病理組織学的ならびに酵 素組織化学的に検案し, 以下の結果を得た。
I. 組織学的所見

家兔の顎下腺に移植された VX2 癌組織は経週的に増 殖, 増大し, それにともない終末部腺房細胞の萎縮, 変 形, 核の濃縮, 変形, さらには介在部や線条部の導管上 皮細胞の萎縮や 核の濃縮などの退行性変化が認められ た.また，てれにともなって終末部腺房細胞の PAS 陽 性物質む減少していた。ささに，てれらの退行性变化は 経週的にその範囲を増していた。

I. 酵素組織化学的所見

1.コハク酸脱水素酵素 $(\mathrm{SDH})$ 反応：腫瘍組織の増殖 にともない，周团の顎下腺組織では，終末部腺房細胞扝 よび介在部や線条部の導管上皮細胞は徐々に反応が低下 していた，以上の所見はとくに腫湯組織と接する部で著 明にみられ, 組織学的に終末部腺房細胞や介在部および 線条部の導管上皮細胞における細胞質の萎縮, 変形, 核 の濃縮などの退行性変化の範囲とほぼ一致していた。

2. 乳酸脱水素酵素 $(\mathbf{L D H})$ 反応：腫瘍組織に接する 終末部腺房細胞では, 腫瘍組織の増殖にともない, 経週 的に反応は徐々に低下し, 組織学的に終末部腺房細胞の 萎縮, 変形や核の濃縮などの退行性変化の範囲とほぼ一 致していた。しかしながら，腫瘍組織に接する介在部や 線条部の導管上皮細胞では, 移植後 3 週例より細胞質の 萎縮，核の濃縮などの退行性変化とほぼ一致して，しだ い店は低下していた。

3. 酸性フォスファターゼ (ACP) 反応：腫瘍組織に 接する終末部腺房細胞の反応は移植後 2 週例よりしだい に増強し, 組織学的に終末部腺房細胞の萎縮, 変形, 核 の濃縮が強度な部とほほ一致していた。しかしながら， 介在部や線条部の導管上皮細胞では, 細胞質の萎縮, 核 の濃繀などとともに，移植後 3 週例よりしだいに反応は 低下していた。

4. アルカリフォスファターゼ (ALP) 反応 : 腫痬組 織の増殖にともない, 腫瘍組織に接する終末部の筋上皮 細胞では，経週的に反応は徐々に低下し，組織学的に終 末部腺房細胞の萎縮, 変形, 核の濃縮などの退行性変化 の範囲とほぼ一致していた。

6. 非特異的エステラーゼ (EST) 反応：腫瘍組織の 増殖にともない，腫暘組織に接する終末部腺房細胞およ び介在部や線条部の導管上皮細胞の反応は経週的に徐々 に低下し, 組織学的に終末部腺房細胞および介在部や線 条部の導管上皮細胞における細胞質の萎縮, 变形, 核の 濃縮などの退行性変化の範囲とほぼ一致していた。

6. 以上のような酵素反応の変化は，腫湟組織に囲ま れた部や直接接する部の顎下腺組織において, とくに強 
度となり，腫煬組織から離れるにしたがい徐々に軽減し ていた。また，てれらの変化は組織学的に終末的腺房細 胞および介在部や線条部における細胞質の萎縮, 変形, 核の濃縮などの退行性変化とほぼ一致してみられた。

7. 以上の実験成績から，VX2癌組織の浸潤，増殖は 顎下腺組織に形態学的な退行性変化を引き起こすのみな らず，分泌物質の合成，排泄などの機能的な面にまで影 響を与えるものと考えられる。ささらに，終末部の腺房細 胞や筋上皮細胞抽よび導管上皮細胞の䣼素反応に変化を 招来し，顎下腺組織の代謝機構にまで影響を与えるもの
と推察される.

稿を終わるに臨み, 本研究に終始御懇切なる御指導と 御校閲を賜わった恩師・梶山稔教授に深甚なる感謝の 意を表します。また，種々と御教示を戴いた講師・黒川 英雄博士に感謝します.あわせて, 本研究に御協力を戴 いた教室各位に謝意を表わします。

本論文の要旨は第41回日本口腔科学会総会（昭和62年 4 月 6 日，東京）において発表した。

\section{引用 文 献}

1）上野 正・岡 達・清水正涮・小谷 朗・雨宮義弘：口腔癌の療法と予後敒関する研究（第 3 報）下顎癌 122例について. 口病誌 $28: 432-444,1961$.

2 ) Hoye, R.C., Herrold, K.M., Smith, R.R. and Thomas, L.B. : A clinicopathological study of epidermoid carcinoma of the head and neck. Cancer $15: 741-749,1962$.

3) Cady, B. and Catlin, D. : Epidermoid carcinoma of the gum. A 20-year survey. Cancer $23: 551-569,1969$.

4 ) Harrold, C.C. : Management of cancer of the floor of the mouth. Am. J. Surg. 122:487495,1971 .

5 ) Barton, R.T. and Ucmakli, A. : Treatment of squamous cell carcinoma of the floor of the mouth. Surg. Gynecol. Obstet. $145: 21-27,1977$.

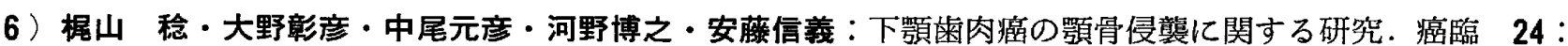
$4-10,1978$.

7 ）富田喜内・戸塚靖則：口腔癌の下顎骨浸潤について. 北海道菌誌 $1 ： 8-16,1980$.

8 ）小浜源郁・山本悦秀・砂川 元：歯肉癌. 歯科シャーナル $14: 663-676,1981$.

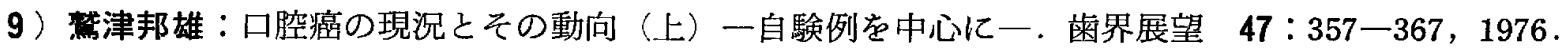

10）鷘津邦雄：口腔癌の現況とその動向（下）一自験例を中心に一。茵界展望 $47: 511-522 ， 1976$.

11）出雲俊之：下顎歯肉扁平上皮癌における骨吸収像. 口病誌 $53: 343-356,1986$.

12）菅原克彦・長尾 桓：癌の集学療法．医学のあゆみ $121: 1015-1025 ， 1982$.

13) Bertino, J.R., Mosher, M.B. and DeConti, R.C. : Chemotherapy of cancer of the head and neck. Cancer $31: 1141-1149,1973$.

14) Richard, J.M., Sancho, H., Lepintre, Y., Rodary, J. and Pierquin, B. : Intra-arterial methotrexate chemotherapy and telecobalt therapy in cancer of the oral cavity and oropharynx. Cancer 34:491-496, 1974.

15）佐藤靖雄・高橋広臣：頭頸部腫瘍の治療。癌之化学療法 1 ：899-910，1975.

16) Hollmann, K., Jesch, W., Kuehboeck, J. and Dimopoulos, J. : Combined intra-arterial chemotherapy and radiation therapy of tumours in the maxillofacial region. J. Maxillofac. Surg. $7: 191-197,1979$.

17) Dhawan, I.K., Thakur, N.S., Madan, N.C., Bannerjee, A. and Sahoo, B.K. : Polychemotherapy in squamous cell carcinoma of buccal mucosa. Cancer $51: 773-777,1983$.

18) Schmieder, A., Jacobs, H., Maurer, H. und Pfeifer, H. : Chemotherapie mit Cisplatin-Bleomycin und nachfolgende Strahlentherapie bei fortgeschrittenen Kopf-Hals-Tumoren. Klin. Wochenschr. 62:35-42, 1984. 
19）塩田重利・天笠光雄：口腔覀性腫瘍治療の現況一とくに舌癌を中心に一．医学のあゆみ $134 ： 955-961$, 1985.

20）暒山 稔：口腔癌と化学療法一局所動脈内㧴管注入療法について一. 九州菌会誌 $39: 874-881,1985$.

21) Macchiarulo, o. und Buengeler, W. : Druch Teer, erzeugte eigenartige Veraenderungen der Parotisdruese. Frankf. Z. Path. $37: 211-221,1929$.

22）岛田牢四郎：吉田肉腫を移植したラット顎下腺について. 歯科医学 $23 ： 1503-1522,1960$.

23）生田信孝：顎下腺における実験的腫瘍形成の研究. 口病誌 $28: 373-386,1961$.

24) Shafer, W.G. : Experimental salivary gland tumorigenesis. J. Dent. Res. $41: 117-124,1962$.

25) Sugimura, $\mathbf{M}$ and Kawakatsu, K. : Histochemical studies of enzymatic patterns during experimental carcinogenesis in the mouse parotid gland. Arch. Oral Biol. 11: 1269-1291, 1966 .

26) Matsumura, T. : Enzyme histochemistry of experimentally induced tumors in the mouse submaxillary and sublingual glands during carcinogenesis. Gann $57: 251-263,1966$.

27）川勝蜸作・森 昌彦・杉村正仁・松村智弘・河野孝行・黒井 満・森下正明：ウサギ顎下腺に移植した VX2 Carcinoma の増殖態度について〔会〕. 日口外誌 $15: 235-236,1969$.

28）安藤龍男：上顎洞癌の増殖態度に関する実験的研究.九州崡会誌 $25: 183-203,1971$.

29）中㟃 武：20-methylcholanthrene による睡液腺腫煬の発生に関する実験的研究 とくに肉腫型腫痬につ いて. 岩手医誌 $25: 572-588,1973$.

30）杉村正仁・椿本雅有・藤村英典・川勝蜸作：家鬼 VX2 Carcinoma 移植による上顎洞癌モデルについて. 口科誌 $22: 380-393,1973$.

31) Kim, S., Spencer, H.H., Weatherbee, L. and Nasjleti, C.E. : Changes in secretory cells during early stages of experimental carcinogenesis in the rat submandibular gland. Cancer Res. $34: 2172-2183,1974$.

32）椿本雅宥：上顎洞に移植した VX2 担癌家鬼における線溶・凝固系の変化と転移形成に関する研究. 阪大蒾 学誌 $19: 6-18,1974$.

33) Englander, A. and Cataldo, E. : Experimental carcinogenesis in duct-artery ligated rat submandibular gland. J. Dent. Res. $55: 229-234,1976$.

34）塩田 党・南 英治・角野博俊・小野尊睦：20-Methylcholanthrene に上る実験的口腔腫瑒に関する研究. 京大口科紀要 $17: 1-9,1977$.

35）塩田 覚・南 英治・吉武一貞・小野尊睦：実験的喠液腺腫掦に関する研究. 京大口科紀要 $18: 28-38$, 1978 .

36) 外山勤吾 : VX2 癌移植による家鬼舌癌の病理組織学的研究. 九州歯会誌 $32: 340-356,1978$.

37）河原和子・熊谷克彦・二階宏昌：7，12-DMBAにより誘発されたマウス㖽下腺腫瘍一光顕的にみた病理組 織像一. 広大歯誌 $11: 115-124,1979$.

38）杉浦正幸：口腔領域における移植腫煌による浸潤発育様式の病理組織学的研究. 口科誌 $32: 350-371$, 1983 .

39）中村憲司：家兔の䫈下腺に扔ける VX2 癌の增殖に関する実験的研究. 九州幽会誌 $38: 455-470,1984$.

40) 中尾元彦：家鬼菌肉癌 (VX2 癌) の下枵骨侵襲に関する実験的研究 九州歯会誌 $40: 188-204,1986$.

41) Shope, R.E. : Infection's papillomatosis of rabbits with a note on the histopathology. J. Exp. Med. 58 : 607-610, 1933.

42) Kidd, J.G. and Rous, P. : A transplantable rabbit carcinoma orginating in a virus-induced papilloma and containing the virus in masked or altered form. J. Exp. Med. $71: 813-$ $849,1940$.

43）佐野 僼：組織学研究法一理論と術式一. 南山堂, 東京, 1965, 505-517. 
44) Barka, T. and Anderson, P.J. : Histochemical methods for acid phosphatase using hexazonium pararosanilin as coupler. J. Histochem. Cytochem. 10:741-753, 1962.

45) Watanabe, K. and Fishman, W.H. : Application of the stereospecific inhibitor L-phenylalanine to the enzymorphology of intestinal alkaline phosphatase. J. Histochem. Cytochem. $12: 252-260,1964$.

46) Burstone, M.S. : Esterases. In: Enzyme histochemistry and Its application in the study of neoplasms. Academic Press, New York, 1962, 324-325.

47）立花忠夫：口腔領域扁平上胞癌の钼部りンパ節転移に関する臨床的ならびに病理組織学的研究. 口病誌 $52: 521-544,1985$.

48) Jakobsson, P. Å., Eneroth, C.M., Killander, D., Moberger, G. and Mårtensson, B. : Histologic classification and grading of malignancy in carcinoma of the larynx. Acta Radiol. $12: 1-8,1973$.

49) Willén, R., Nathanson, A., Moberger, G. and Anneroth, G. : Squamous cell carcinoma of the gingiva. Histological classification and grading of malignancy. Acta Otolaryngol. $79: 146-154,1975$.

50）芝 良祐：ラット顎下腺および舌下腺における排出管結紮の影響について．阪大歯学誌 $12: 23-33 ， 1967$.

51）園部英俊：家鬼耳下腺排泄管結紮江関する実験的研究一組織化学的検索. 日口外誌 $24: 1091-1107,1978$.

52）黒川英雄：家鬼耳下腺におよぼす制癌剤の影響に関する実験的研究. 九州歯会誌 $36: 1012-1033 ， 1982$.

53）浅野蜸一：唾液腺導管結禁に関する実験的研究一病理学的, 組織化学的研究一. 口科誌 $35: 216-238$, 1986.

54）橋本建治：睡液の流出障害をおこさせたイ又顎下腺の変化に関する組織化学的研究. 九州歯会誌 40 ： 986-1004, 1986 .

55) Hill, C.R. and Bourne, G.H. : The histochemistry and cytology of the salivary gland duct cells. Acta Anat. $20: 116-128,1954$.

56) Scott, B.L. and Pease, D.C. : Electron microscopy of the salivary and lacrimal glands of the rat. Am. J. Anat. $104: 115-161,1959$.

57）川勝置作・森 昌彦・福田道男・藤田訓也・保志信男 : 正常娷液腺の組織化学的研究 第 I 報 コハク酸脱 水素酵素の組織化学的証明. 阪大菌学誌 $4: 421-438,1959$.

58) Kawakatsu, K. and Mori, M. : Histochemical study of enzyme patterns in the human submaxillary gland. Histochemie. 2 : 393-401, 1962.

59) Handelman, C.S. and Wells, H. : Morphological and histochemical studies of experimentally enlarged and atrophied salivary glands of rats. Am. J. Anat. 112:65-79, 1963.

60）森昌彦：睡液腺導管の Enzyme Histochemistry とその微細構造. 細胞化学シンポジウム $13: 339$ $351,1963$.

61）川勝置作・福田道男：組織化学とその現状（その 3 ）睡液腺の組織化学. 歯界展望 $22: 273-279,1963$.

62）北島光彦：排出管結禁棰液腺の組織学的ならびに組織化学的研究. 崡科医学 $23: 507-527,1960$.

63）武田泰典・竹下信義・鈴木鍾美：顎下腺の萎縮性変化に関する病理組織学的研究検討 [会]. 歯基礎誌 $23: 97,1981$.

64) Bogart, B.I. : The fine structural localization of alkaline and acid phosphatase activity in the rat submandibular gland. J. Histochem. Cytochem. $16: 572-581,1968$.

65）森下正明：X線照射の実験腫晹におよぼす影響に関する研究. 阪大粜学誌 $13: 139-149,1968$.

66）倉橋和啓：ライソゾームの機能. 細胞 $2: 14-25,1970$.

67）本川 渉：ラット舌乳頭味蕾のフォスファターゼに関する組織化学的研究. 九州霜会誌 $31: 574-596$, 1978. 
68）馬屋原 宏：Acid phosphatase. 新酵素組織化学 (小川和朗・他編)。朝倉書店, 東京，1985，298一 314.

69）川勝叹作・森 昌彦・藤田訓也・谷 孝夫：正常唾液腺の組織化学的研究 N.Acid phosphatase の組 織化学的証明. 日組録 $19: 473-481,1960$.

70) Chauncey, H.H. and Quintarelli, G. : Localization of acid phosphatase, nonspecific esterase and $\beta-\mathrm{D}$-galactosidase in parotid and submaxillary glands of domestic and laboratory animals. Am. J. Anat. $108: 263-293,1961$.

71）川勝賢作・森 昌彦・藤田訓也・福田道男・川䞚輝盛：正常唾液腺の組織化学的研究 第 III 報 Alkaline phosphatase の組織化学的証明. 阪大歯学誌 $4: 455-470,1959$.

72）森. 昌彦：日腔領域に抢ける組織化学.日口外誌 9：207-229，1963.

73) Shear, M. : The structure and function of myoepithelial cells in salivary glands. Arch. Oral Biol. $11: 769-780,1966$.

74) Monis, B. and Rutenburg, A.M. : Alkaline phosphatase activity in neoplastic and inflammatory tissues of man. Cancer $13: 538-544,1960$.

75）川勝䍝作・岡 隆一：組織化学とその現状 (その2）口腔領域腫瘍の組織化学. 歯界展望 22:19一25, 1963.

76) 森 昌彦：組織化学的診断. 粜科ジャーナル $14: 723-727,1981$.

77) Moul'e, Y. : Endoplasmic reticulum and microsomes of rat liver. In: Cellular membranes in development (ed. by Locke, M.). Academic Press, New York, 1964, 97-133. 